\title{
A Comparative NMR Study on the Reactions of Hf(IV) Organometallic Complexes with Al/Zn Alkyls
}

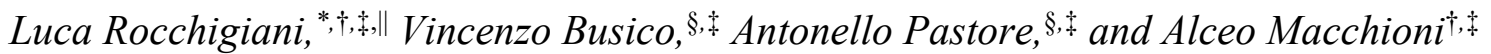

\begin{abstract}
'Dipartimento di Chimica, Biologia e Biotecnologie and CIRCC, Università degli studi di Perugia, Via Elce di sotto, 8, I-06123 Perugia, Italy. ${ }^{\S}$ Dipartimento di Scienze Chimiche, Università di Napoli Federico II, Via Cintia, I-80126 Napoli, Italy. ${ }^{*}$ Dutch Polymer Institute (DPI) PO box 902, 5600 AX Eindhoven, The Netherlands. "Current address: School of Chemistry, University of East Anglia, Norwich NR4 7TJ, UK.
\end{abstract}

email: L.Rocchigiani@uea.ac.uk

\begin{abstract}
NMR spectroscopy has been exploited to investigate the reactions of $\mathrm{Hf}(\mathrm{IV})$ organometallic complexes with trialkylaluminium and dialkylzinc, with the aim of obtaining insights into the elementary steps of coordinative chain transfer polymerization (CCTP). Bis-cyclopentadienyl hafnium dimethyl $\left(\mathrm{Cp}_{2} \mathrm{HfMe}_{2}, \mathbf{1} \mathbf{M e}_{2}\right)$ and [N-[2,6-Diisopropylphenyl]- $\alpha$-[2-isopropylphenyl]-6-(1-naphthalenyl)-2pyridinemethanaminato]hafnium dimethyl (2Me $)$ complexes have been chosen as case studies for understanding the differences between poorly performing and highly active CCTP catalysts, in an attempt to assess the effect of the ancillary ligand on the transalkylation rate. $\mathbf{2} \mathbf{M e}_{2}$ was found to react much faster with both $\mathrm{AlEt}_{3}$ and $\mathrm{ZnEt}_{2}$ than $\mathbf{1} \mathbf{M e}_{2}$, mainly due to a remarkably lower activation enthalpy. In addition, while the ethylation rate was found to depend on the nature of the alkylating agent for $\mathbf{1} \mathbf{M e}_{2}$, it does not for $\mathbf{2} \mathbf{M e}_{2}$. This difference in reactivity was observed also in the case of the ion pairs obtained by reacting $\mathbf{1} \mathbf{M e}_{2}$ and $\mathbf{2} \mathbf{M e}_{2}$ with $\left[\mathrm{CPh}_{3}\right]\left[\mathrm{B}\left(\mathrm{C}_{6} \mathrm{~F}_{5}\right)_{4}\right]$. For the latter species, NMR indicated that two main deactivation pathways, namely anion decomposition and $\sigma$-bond methatesis of Hfalkyl groups, occur.
\end{abstract}

\section{Introduction}

Chain transfer reactions between transition organometallic complexes and main element alkyls play a crucial role in homogeneous olefin polymerization catalysis. ${ }^{1}$ Polymeryl-group migration from active sites to co-catalysts, most frequently aluminium alkyls or methylaluminoxane (MAO), ${ }^{2,3}$ is indeed a suitable chain termination process that can be exploited in tuning molecular weight and endgroup structures of resulting polyolefins. ${ }^{4}$ This is particularly true in the case of living polymerization, ${ }^{5}$ since chain transfer increases the number of chains produced by each catalytic site and decreases the polydispersity. ${ }^{6}$ This concept is key in coordinative chain transfer polymerization (CCTP, Scheme 
1), ${ }^{7}$ a reaction protocol based on the addition of chain transfer agents, such as $\mathrm{AlR}_{3}, \mathrm{ZnR}_{2}$ or $\mathrm{MgR}_{2}$, to the catalytic pool, aimed at stimulating fast and reversible alkyl exchange between active transition metal and main element. As a matter of fact, when CCTP conditions are attained, chain transfer occurs faster than monomer insertion $\left(k_{\mathrm{CT}}>>k_{\mathrm{P}}\right.$, Scheme 1$)$ resulting in polymers with extremely narrow molecular weight distributions. ${ }^{8}$

From the mechanistic point of view, the key step of CCTP relies on the formation of binuclear adducts in which polymeryl groups act as bridges between transition metal and main metal centers (Scheme 1). ${ }^{7}$ Despite rather intensive research in this area, little is known about adducts between active catalysts for CCTP and main metal alkyls, mainly due to their dynamic nature and low stability in solution. In a few cases, well defined $\mathrm{L}_{n} \mathrm{M}(\mu-\mathrm{R})_{\mathrm{n}} \mathrm{ER}_{\mathrm{m}}(\mathrm{M}=$ transition metal, $\mathrm{E}=$ main metal) heterobimetallic adducts have been characterized, including group IV metallocenes, ${ }^{9}$ rare earth-metal ${ }^{10}$ or bisiminopyridyl $\mathrm{V}^{11}{ }^{\mathrm{Fe}^{12}}$ and $\mathrm{Co}^{13}$ complexes, but only when $\mathrm{E}=\mathrm{Al}$. Recently, we have shown that cationic pyridylamido Hf complexes, ${ }^{14}$ which are remarkably active catalysts for CCTP,${ }^{8,15}$ react with zinc and aluminium alkyls to give heterobimetallic adducts. In the latter ones, the cyclometalated naphthyl group acts as a bridge between hafnium and main metal atoms, closely resembling the proposed intermediate for CCTP. ${ }^{16}$ The investigation of degenerative alkyl transfer kinetics revealed that $\mathrm{Hf} / \mathrm{Zn}$ methyl exchange was faster than Hf/Al one, suggesting that the nature of metal alkyl is key in tuning the fluxionality of such adducts.

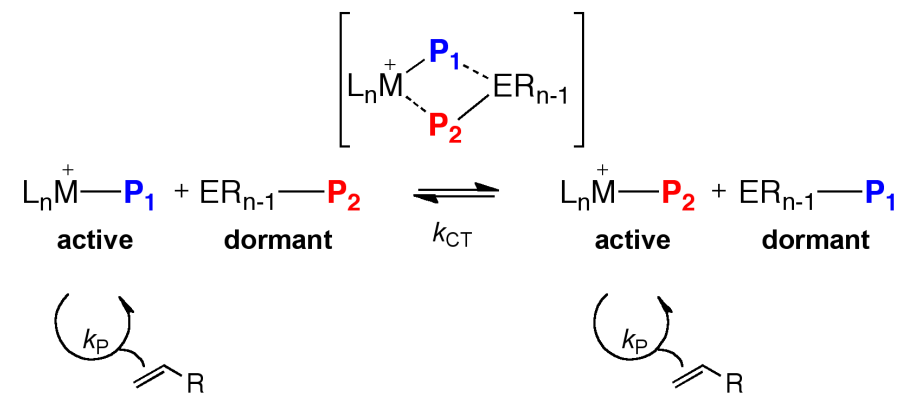

Scheme 1. Mechanism of coordinative chain transfer polymerization $(M=$ transition metal, $\mathrm{E}=$ main element).

Nuclear Magnetic Spectroscopy has proven to be a suitable technique for mechanistic investigations of homogeneous olefin polymerization ${ }^{17}$ and, in the present study, we exploited NMR for studying the reactivity of biscyclopentadienyl- and (pyridylamido)hafnium complexes with $\mathrm{ZnR}_{2}$ and $\mathrm{AlR}_{3}(\mathrm{R}=\mathrm{Me}$ or $\mathrm{Et})$. The main purpose of this work is to compare the behavior of the simplest hafnocene $\mathrm{Cp}_{2} \mathrm{HfMe}_{2}\left(\mathbf{1 M e}_{2}\right.$, Scheme 2), which is not a suitable catalyst for chain transfer polymerization, with that of the highly optimized pyridylamido complex $\left(\mathbf{2} \mathbf{M e}_{2}\right.$, Scheme 2$)$ that is one of the most effective group IV catalysts in CCTP. First, we investigated the reactivity of mixtures containing $\mathrm{ZnEt}_{2}$ and $\mathrm{AlEt}_{3}$. Secondly, a kinetic study of their reactions with hafnium dimethyl species was car- 
ried out for evaluating the effect of the ancillary ligand on the activation parameters. Then, the reactivity of $\mathrm{Zn}$ - and Al-alkyls with cationic metallocenium species was explored and compared to that of the previously reported pyridylamido cationic complexes. Finally, the thermal decomposition of pyridylamido-Zn/Al heterobimetallic adducts was studied for understanding the role of chain transfer agent in deactivating the catalytic system.
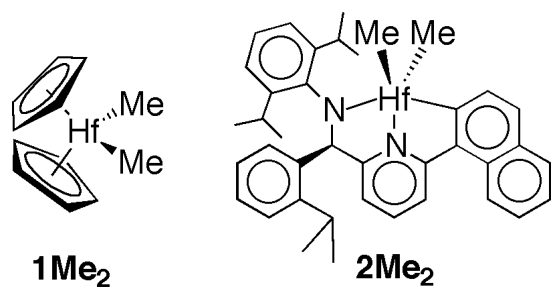

Scheme 2. Hafnium complexes considered in this study.

\section{Results and discussion}

\section{1. $\mathrm{AlEt}_{3} / \mathrm{ZnEt}_{2}$ mixtures}

${ }^{1} \mathrm{H}$ and ${ }^{13} \mathrm{C}$ NMR spectra of a $1: 1 \mathrm{AlEt}_{3} / \mathrm{ZnEt}_{2}$ mixture in toluene- $d_{8}$ showed the presence of only one set of signals at room temperature, having chemical shift values equal to the average of those of pure components. This indicates that a fast ethyl exchange process between aluminum and zinc atoms does occur, as already reported for $\mathrm{AlMe}_{3} / \mathrm{ZnMe}_{2}$ mixtures. ${ }^{18}$ Nevertheless, at low temperature the process became slow with respect to the NMR timescale and three different sets of signals separated below $200 \mathrm{~K}$ (Figure 1a); they were assigned to a) the ethyl group bound to the $\mathrm{Zn}$ atom $\left.\left[\delta_{\mathrm{H}}\left(\mathrm{CH}_{2}\right)=0.09 \mathrm{ppm}\right], b\right)$ the terminal $\left[\delta_{\mathrm{H}}\left(\mathrm{CH}_{2}\right)=0.16 \mathrm{ppm}\right.$ and $c$ ) the bridging $\left[\delta_{\mathrm{H}}\left(\mathrm{CH}_{2}\right)=0.67 \mathrm{ppm}\right]$ ethyl groups of the $\mathrm{AlEt}_{3}$ dimer. ${ }^{19}$ The simulation of the VT NMR spectra was hampered by the presence of many signals with different populations and only approximate rate constant values for alkyl exchange were derived in this specific case. For example, coalescence between unbridging methylene signals of $\mathrm{AlEt}_{3}$ and $\mathrm{ZnEt}_{2}$ was detected at $210 \mathrm{~K}$ and an approximate rate constant of $70 \mathrm{~s}^{-1}$ was calculated $\left(\Delta \mathrm{G}^{\neq}=10.3 \mathrm{kcal} / \mathrm{mol}\right){ }^{20}$ 


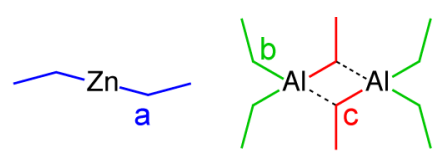

a)

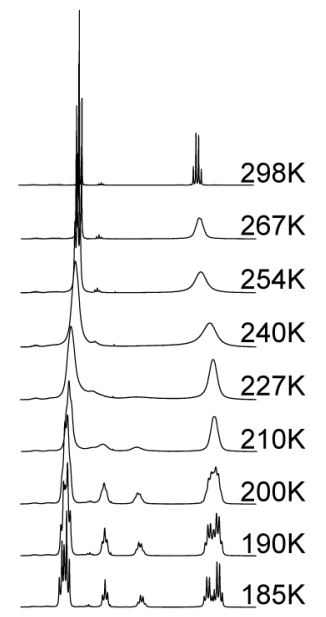

b)

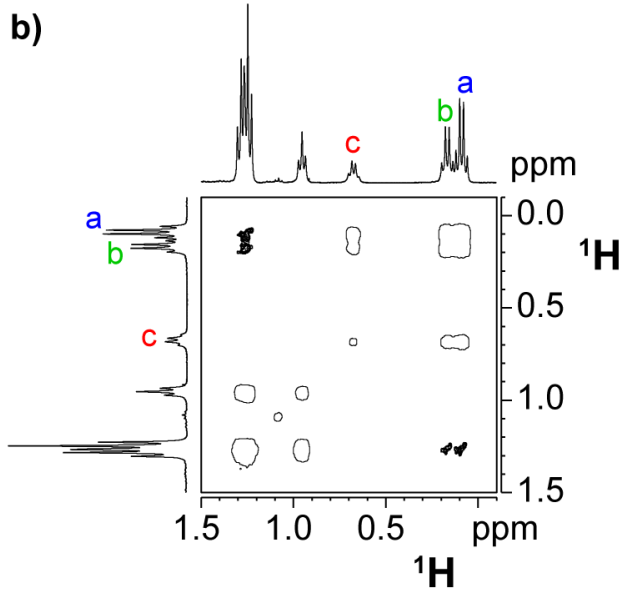

Figure 1. a) VT ${ }^{1} \mathrm{H}$ NMR spectra of a 1:1 mixture of $\mathrm{AlEt}_{3}$ and $\mathrm{ZnEt}_{2}$ in toluene- $d_{8}$; b) ${ }^{1} \mathrm{H}$ NOESY NMR spectrum recorded at $185 \mathrm{~K}$.

At $185 \mathrm{~K}$, the ${ }^{1} \mathrm{H}$ NOESY NMR spectrum of the mixture (Figure 1b) showed the presence of intense exchange cross peaks, revealing that the alkyl exchange occurs also at rather low temperatures. Interestingly, the bridging ethyl groups of $\mathrm{AlEt}_{3}$ dimer were in exchange with both terminal and $\mathrm{Zn}$ ethyl groups, likely owing to the dissociation/recombination process of the $\mathrm{Al}$ dimer. ${ }^{18 a, 19}$ Additionally, the uniform signal broadening with temperature observed in VT ${ }^{1} \mathrm{H}$ NMR spectra suggested the presence of a unique kinetic constant for all the exchanges. This could be explained assuming the dissociation of the $\mathrm{AlEt}_{3}$ dimer as rate determining step, as already suggested for the $\mathrm{AlR}_{3} / \mathrm{GaR}_{3}$ exchange. ${ }^{18 \mathrm{a}}$

\section{2. $1 \mathrm{Me}_{2} / \mathbf{E R}_{\mathrm{n}}$ mixtures}

The reaction of $\mathbf{1} \mathbf{M e}_{2}$ with an excess of $\mathrm{ZnEt}_{2}$ or AlEt 3 in benzene- $d_{6}$ led to the formation of $\mathrm{Cp}_{2} \mathrm{HfMeEt}(\mathbf{1 M e E t})$ and $\mathrm{Cp}_{2} \mathrm{HfEt}_{2}\left(\mathbf{1 E t} \mathbf{t}_{2}\right.$, Scheme 3), as indicated by the appearance of two overlapped signals at $\delta_{\mathrm{H}}=1.45 \mathrm{ppm}\left({ }^{3} \mathrm{~J}_{\mathrm{HH}}=7.8 \mathrm{~Hz},{ }^{1} \mathrm{~J}_{\mathrm{C}, \mathrm{H}}=124.6 \mathrm{~Hz}\right)$ in the ${ }^{1} \mathrm{H}$ NMR spectrum. They were assigned to the $\mathrm{CH}_{3}$ groups of the Hf-ethyl moieties, in agreement with previous observations. ${ }^{21}$

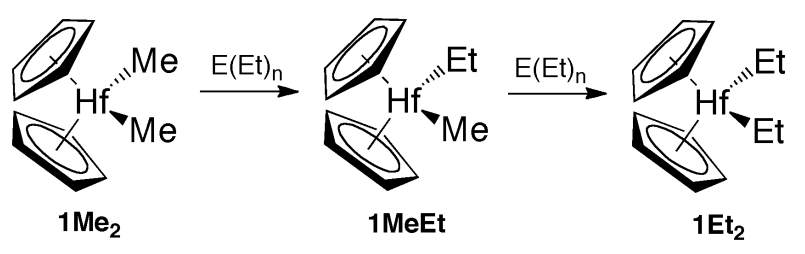

Scheme 3. Ethyl transfer from $E(E t)_{n}$ to $\mathbf{1} \mathbf{M e}_{2}$. 
In contrast with zirconocenes, ${ }^{21}$ ethyl transfer reactions occur slowly at room temperature. For instance, $80 \%$ conversion of $\mathbf{1} \mathbf{M e}_{2}$ into $\mathbf{1 M e E t}$ and $\mathbf{1 E t} \mathbf{t}_{2}$ was obtained after 17 hours in the presence of 30 equivalents of $\mathrm{ZnEt}_{2}$ at room temperature. $\mathbf{1} \mathbf{M e}_{2}$ was instead consumed in approximately 85 minutes when 2 equivalents of $\mathrm{AlEt}_{3}$ were used (Figure 2). Ethylated hafnocenes showed to be remarkably stable in solution up to $350 \mathrm{~K}$, even if traces of ethane $\left(\delta_{\mathrm{H}}=0.80 \mathrm{ppm}\right)$ were detected during the reactions, in particular at temperatures above $320 \mathrm{~K}$.

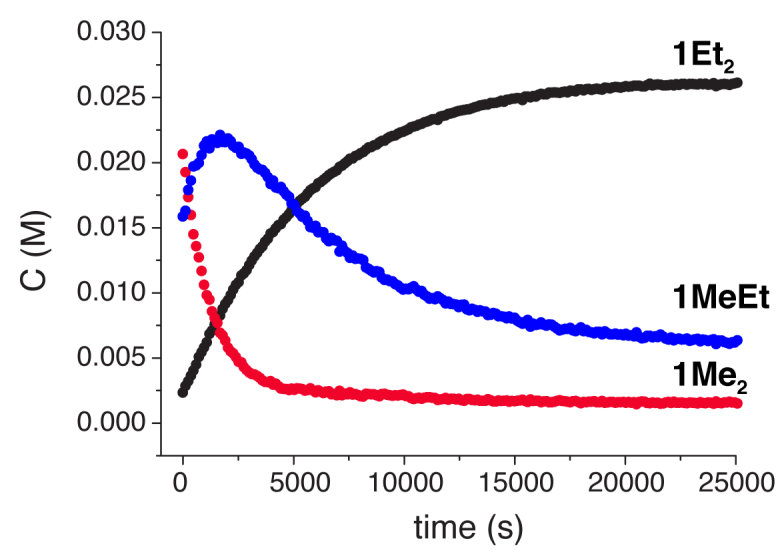

Figure 2. Concentration versus time plot obtained for the reaction of $\mathbf{1} \mathbf{M e}_{2}$ with 2 equivalents of $\mathrm{AlEt}_{3}$ in toluene- $d_{8}$ at $298 \mathrm{~K}$.

Kinetic profiles of methyl-to-ethyl transalkylation at variable temperature were obtained by following the evolution of the ${ }^{1} \mathrm{H}$ NMR spectra with time, as depicted in Figure 2. By a qualitative analysis, it is possible to note that the first ethylation is markedly faster than the second one and the concentration of $\mathbf{1 M e E t}$ shows a maximum that is dependent on both temperature and $\mathrm{Hf} / \mathrm{ER}_{\mathrm{n}}$ ratio. These observations are consistent with a consecutive reaction pathway, in which $\mathbf{1 E t}_{\mathbf{2}}$ is formed only from $\mathbf{1 M e E t}$ and not owing to a double ethylation of $\mathbf{1} \mathbf{M e}_{2}$.

Table 1 collects kinetic constants obtained for first $\left(k_{1}\right)$ and second $\left(k_{2}\right)$ alkylation of $\mathbf{1} \mathbf{M e}_{2}$ with $\mathrm{ZnEt}_{2}$ and $\mathrm{AlEt}_{3}$ at different reaction temperatures (Experimental Section for details). The results show that the first alkyl exchange reaction is 2-4 times faster than the second, independent of the alkylating agent. On the other hand, the main group metal plays a crucial role since reactions with $\mathrm{AlEt}_{3}$ are notably faster than those with $\mathrm{ZnEt}_{2}$. As an example, at $300 \mathrm{~K}$ kinetic constants obtained in the case of aluminium are twenty times larger than those obtained with zinc.

Table 1. Second-order rate constants $\left(\mathrm{M}^{-1} \mathrm{~s}^{-1}\right)$ for first $\left(k_{1}\right)$ and second $\left(k_{2}\right)$ ethylation of $\mathbf{1} \mathbf{M e}_{2}$ obtained at different temperatures $(\mathrm{K})$ with different alkylating agents.

\begin{tabular}{|c|c|c|c|c|}
\hline & \multicolumn{2}{|c|}{$\mathbf{Z n E t}_{\mathbf{2}}$} & \multicolumn{2}{c|}{$\mathbf{A l E t}_{\mathbf{3}}$} \\
\hline $\mathbf{T}$ & $\boldsymbol{k}_{\mathbf{1}}$ & $\boldsymbol{k}_{\mathbf{2}}$ & $\boldsymbol{k}_{\mathbf{1}}$ & $\boldsymbol{k}_{\mathbf{2}}$ \\
\hline 267.5 & - & - & $(6.6 \pm 0.2) \cdot 10^{-5}$ & $(2.7 \pm 0.2) \cdot 10^{-5}$ \\
\hline 273.8 & - & - & $(1.5 \pm 0.3) \cdot 10^{-4}$ & $(4.9 \pm 0.8) \cdot 10^{-5}$ \\
\hline
\end{tabular}




\begin{tabular}{|c|c|c|c|c|}
\hline 287.3 & - & - & $(4.9 \pm 0.6) \cdot 10^{-4}$ & $(1.8 \pm 0.1) \cdot 10^{-4}$ \\
\hline 300.1 & $(7.5 \pm 0.6) \cdot 10^{-5}$ & $(3.1 \pm 0.3) \cdot 10^{-5}$ & $(1.6 \pm 0.2) \cdot 10^{-3}$ & $(5.5 \pm 1.8) \cdot 10^{-4}$ \\
\hline 320.6 & $(4.1 \pm 0.6) \cdot 10^{-4}$ & $(1.0 \pm 0.2) \cdot 10^{-4}$ & - & - \\
\hline 342.4 & $(2.4 \pm 0.4) \cdot 10^{-3}$ & $(5.2 \pm 0.9) \cdot 10^{-4}$ & - & - \\
\hline 349.5 & $(4.1 \pm 0.7) \cdot 10^{-3}$ & $(8.5 \pm 1.3) \cdot 10^{-4}$ & - & - \\
\hline
\end{tabular}

The Eyring analysis of $k_{1}$ values (Figure 3) allowed the transalkylation activation parameters to be determined. In the case of $\mathrm{ZnEt}_{2}$, the activation enthalpy is equal to $16.2 \pm 0.3 \mathrm{kcal} / \mathrm{mol}$ and the activation entropy amounts to $-22 \pm 1 \mathrm{cal} / \mathrm{mol} \cdot \mathrm{K}$ while, for $\mathrm{AlEt}_{3}$, a similar $\Delta \mathrm{S}^{\ddagger}(-23 \pm 2 \mathrm{cal} / \mathrm{mol} \cdot \mathrm{K})$ and a lower $\Delta \mathrm{H}^{\ddagger}(14.6 \pm 0.5 \mathrm{kcal} / \mathrm{mol})$ are obtained.

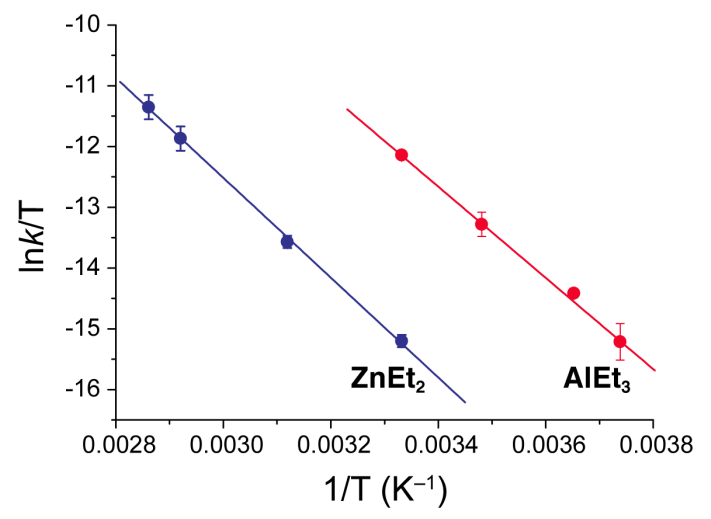

Figure 3. Eyring plots for the ethylation of $\mathbf{1} \mathbf{M e}_{2}$ with $\mathrm{ZnEt}_{2}$ and $\mathrm{AlEt}_{3}$ in toluene- $d_{8}$.

In the case of $\mathrm{Al}$-alkyls, the complication derived from the formation of $\mathrm{Al}_{2} \mathrm{R}_{6}$ dimers, which might affect the trans-alkylation kinetics, has to be taken into account. For this reason, reactions of $\mathbf{1 M e}_{2}$ with variable amounts of $\mathrm{AlEt}_{3}(1: 1,2: 1$ and 4:1 Al/Hf ratios) were performed. The kinetic model was modified slightly to take into account possible equilibrium effects ascribed to the lower concentration of $\mathrm{AlEt}_{3}$. Interestingly, rate constant values at $298 \mathrm{~K}$ are three times larger when hafnocene and aluminium alkyl are equimolar $\left(k_{1}=4.83 \cdot 10^{-3} \mathrm{M}^{-1} \mathrm{~s}^{-1}\right)$ while decrease by increasing the concentration of $\mathrm{AlEt}_{3}$ to reach a plateau at an $\mathrm{Al} / \mathrm{Hf}$ ratio between 5 and 10 (Supporting Information).

It was also considered worthwhile to perform a reaction between $\mathbf{1} \mathbf{M e}_{2}$ and a mixture of $\mathrm{ZnEt}_{2} / \mathrm{AlEt}_{3}$ in a 1:1:1 molar ratio, with the aim of exploring the role of the fast ethyl exchange between $\mathrm{Zn}$ and $\mathrm{Al}$ atoms in the alkylation of the transition metal complex. The quantification of the kinetic rate constants gave a $k_{1}$ value of $2.4 \cdot 10^{-3} \mathrm{M}^{-1} \mathrm{~s}^{-1}$, which is quite similar to the values obtained in the experiment with only $\mathrm{AlEt}_{3}$ at lower $\mathrm{Al} / \mathrm{Hf}$ ratios (Supporting Information).

The analysis of the results reveals that the ethylation of $\mathbf{1} \mathbf{M e}_{2}$ by $\mathrm{ZnEt}_{2}$ and $\mathrm{AlEt}_{3}$ is a slow reaction with a rather high activation barrier $\left(\Delta \mathrm{G}^{\neq}=22.7\right.$ and $21.4 \mathrm{kcal} / \mathrm{mol}$ for $\mathrm{ZnEt}_{2}$ and $\mathrm{AlEt}_{3}$, respectively) that is composed by a large activation enthalpy ( $16.2 \mathrm{kcal} / \mathrm{mol}$ for $\mathrm{ZnEt}_{2}$ and $14.6 \mathrm{kcal} / \mathrm{mol}$ for $\left.\mathrm{AlEt}_{3}\right)$ and a negative activation entropy ( -22 and $-23 \mathrm{cal} / \mathrm{mol} \cdot \mathrm{K}$ for $\mathrm{ZnEt}_{2}$ and $\mathrm{AlEt}_{3}$, respectively). 
The latter values fit nicely with previously reported data on degenerative methyl transfer between $\mathbf{1 M e}_{2}$ and $\mathrm{AlMe}_{3}{ }^{22}$ and are consistent with an associative mechanism, in which the main element alkyl and metallocene form a heterobimetallic complex featuring one or more bridging alkyl groups. Since similar $\Delta \mathrm{S}^{\ddagger}$ values were measured for $\mathrm{ZnEt}_{2}$ and $\mathrm{AlEt}_{3}$, it is reasonable to assume that the reaction pathway is the same for both. Moreover, the activation entropy value points out that the dissociation/recombination of $\mathrm{AlEt}_{3}$ dimer is not rate determining. $\mathrm{AlEt}_{3}$ dimerization has a modest detrimental effect, as deduced by the slightly higher reaction rates at lower $\mathrm{Al} / \mathrm{Hf}$ ratios, likely due to a higher amount of $\mathrm{Al}_{2} \mathrm{Et}_{6}$ dimers that dissociate to monomeric $\mathrm{AlEt}_{3}$, thus increasing the alkylation efficiency. Concerning the activation enthalpy, the lowest $\Delta \mathrm{H}^{\ddagger}$ value observed for $\operatorname{AlEt}_{3}\left(\Delta \Delta \mathrm{H}^{\ddagger}(\mathrm{Zn}\right.$-Al) $=1.6$ $\mathrm{kcal} / \mathrm{mol}$ ) could be related to the higher tendency of the latter of forming dimers with metallocenes and stronger E-Me bonds. ${ }^{23}$ The associative transition state should be, in effect, stabilized by Hf- $(\mu-$ $\mathrm{Me})-\mathrm{ER}_{\mathrm{n}}$ bridges, whose formation is preferred with Al-alkyls.

Finally, the results obtained on the ethylation of $\mathbf{1} \mathbf{M e}_{2}$ with a 1:1 $\mathrm{AlEt}_{3} / \mathrm{ZnEt}_{2}$ mixture are coherent with the proposed mechanistic scenario. The observation of reaction rates similar to those measured with pure $\mathrm{AlEt}_{3}$ confirms that $i$ ) the $\mathrm{Al} / \mathrm{Zn}$ ethyl exchange is not rate determining and ii) there are no cooperative effects, so that the reaction rate is determined by the alkylation of the most efficient metal-alkyl.

\section{3. $2 \mathrm{Me}_{2} / \mathbf{E R}_{\mathrm{n}}$ mixtures}

The reaction of $\mathbf{2} \mathbf{M e}_{2}$ with 1 equivalent of $\mathrm{ZnEt}_{2}$ in benzene- $d_{6}$ afforded a mixture of stable mono- and bis-ethylated complexes, as seen above for $\mathbf{1} \mathbf{M e}_{2}$. Four different Hf-ethyl groups were observed in the ${ }^{1} \mathrm{H}$ NMR spectrum, with methyl groups resonating at $\delta_{\mathrm{H}}=1.75, \delta_{\mathrm{H}}=1.72, \delta_{\mathrm{H}}=1.53$ and $\delta_{\mathrm{H}}=1.44 \mathrm{ppm}\left({ }^{3} \mathrm{~J}_{\mathrm{HH}}=8.0 \mathrm{~Hz}\right.$ ). They were assigned to $i$ ) the two diastereotopic (anti and syn with respect to the 2-( $\left(\mathrm{Me}_{2} \mathrm{CH}\right)-\mathrm{C}_{6} \mathrm{H}_{4}$ substituent) Hf-Et moieties of $\mathbf{2} \mathbf{E t}_{2}$ and ii) the ethyl groups of the two equally populated diastereoisomeric 2MeEt species (Scheme 4). When 1 equivalent of AlEt $_{3}$ was used, the same reactivity was observed. However, some resonances of reaction products appeared slightly broadened, likely due to dynamic processes. Contrary to what was observed with $\mathrm{ZnEt}_{2}$, the reaction mixture was unstable at room temperature and slow decomposition of $\mathrm{AlEt}_{3}$ to ethane occurred. 


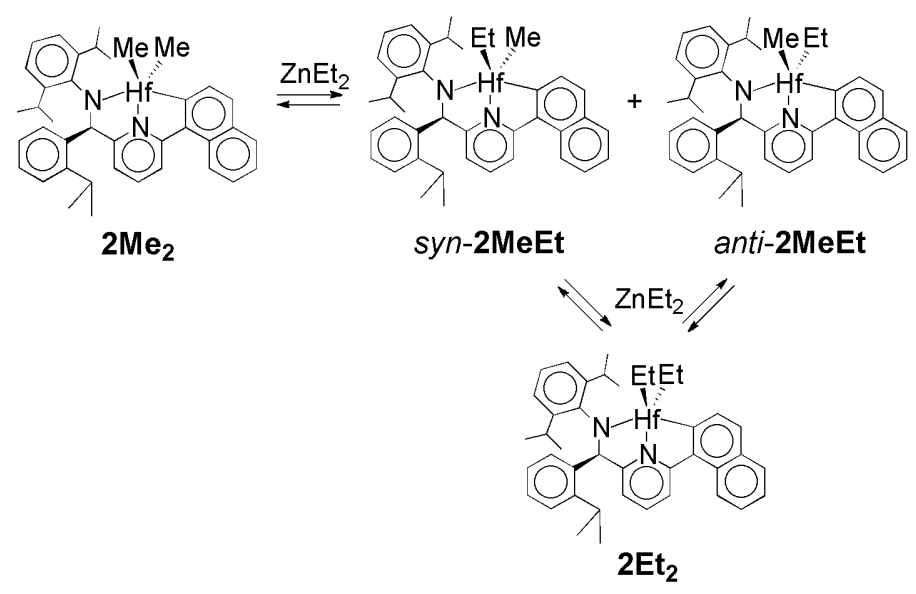

Scheme 4. Transalkylation reaction between $\mathbf{2} \mathbf{M e}_{2}$ and $\mathrm{ZnEt}_{2}$.

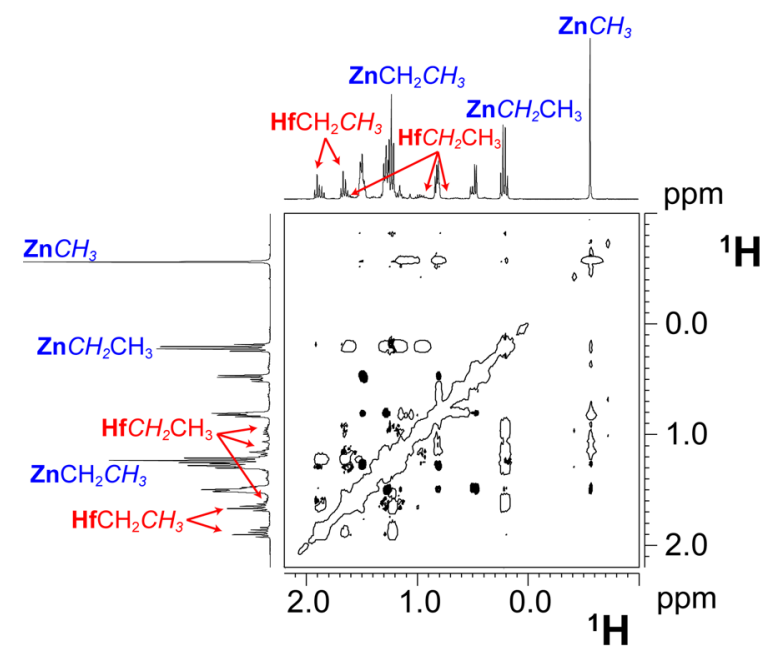

Figure 4. A section of the ${ }^{1} \mathrm{H}$ NOESY NMR spectrum of the mixture obtained after the reaction of

$\mathbf{1 M e}_{2}$ with $\mathrm{ZnEt}_{2}$ (benzene- $d_{6}, 297 \mathrm{~K}$ ).

As far as the reaction rate was concerned, alkyl exchange was very fast with both $\mathrm{ZnEt}_{2}$ and $\mathrm{AlEt}_{3}$ and it was not possible to follow the ethyl transfer by ${ }^{1} \mathrm{H}$ NMR spectroscopy. Nevertheless, the phase sensitive ${ }^{1} \mathrm{H}$ NOESY NMR spectrum of the reaction mixture (Figure 4, $\mathrm{ER}_{\mathrm{n}}=\mathrm{ZnEt}_{2}$ ) revealed the presence of exchange cross peaks between $\mathrm{Zn} / \mathrm{Al}$-alkyl and $\mathrm{Hf}$-alkyl resonances, indicating that a fast and reversible transalkylation occurs at equilibrium. This prompted us to explore the reaction kinetics by means of variable temperature ${ }^{1} \mathrm{H}$ EXSY NMR, ${ }^{24}$ with the aim of obtaining activation parameters to compare with those measured for the reactions of $\mathbf{1} \mathbf{M e}_{2}$.

The kinetic study was performed by using a 5-fold excess of $\mathrm{ER}_{\mathrm{n}}$, in order to promote the exclusive formation of $\mathbf{2 E t}_{2}$ and simplify the NOE spectra (Supporting Information). No exchange between anti and syn ethyl groups of $\mathbf{2} \mathbf{E t}_{\mathbf{2}}$ was detected, indicating that the interconversion of the two alkyls on the metal center is very slow (or frozen), as also observed for $\mathbf{2} \mathbf{M} \mathbf{e}_{2}$. Second order kinetic rate constants were determined from ${ }^{1} \mathrm{H}$ EXSY spectra taking into account the different populations of 
the exchanging sites (Experimental Section). In the case of $\mathrm{AlEt}_{3}$, the temperature window was limited by decomposition, which is faster than the measurement time above $300 \mathrm{~K}$.

Table 2. Second order rate constants $\left(\mathrm{M}^{-1} \mathrm{~s}^{-1}\right)$ for the reversible transalkylation of $\operatorname{syn}\left(k_{\mathrm{syn}}\right)$ and anti ( $\left.k_{\text {anti }}\right)$ ethyl groups of $\mathbf{2} \mathbf{E t}_{2}$ with $\mathrm{ZnEt}_{2}\left(\mathrm{C}_{\mathrm{Hf}}=32.0 \mathrm{mM}, \mathrm{Zn} / \mathrm{Hf}=6\right)$ and $\mathrm{AlEt}_{3}\left(\mathrm{C}_{\mathrm{Hf}}=34.0 \mathrm{mM}, \mathrm{Al} / \mathrm{Hf}=5\right)$ at different temperatures $(\mathrm{T}, \mathrm{K})$.

\begin{tabular}{|c|c|c|c|c|}
\hline & \multicolumn{2}{|c|}{ ZnEt $_{\mathbf{2}}$} & \multicolumn{2}{c|}{ AlEt $_{\mathbf{3}}$} \\
\hline $\mathbf{T}$ & $\boldsymbol{k}_{\text {syn }}$ & $\boldsymbol{k}_{\text {anti }}$ & $\boldsymbol{k}_{\text {syn }}$ & $\boldsymbol{k}_{\text {anti }}$ \\
\hline 273.8 & - & - & $1.5 \pm 0.1$ & $2.8 \pm 1.2$ \\
\hline 287.3 & - & - & $3.4 \pm 0.1$ & $5.4 \pm 1.5$ \\
\hline 300.1 & $3.1 \pm 0.1$ & $3.5 \pm 0.8$ & - & - \\
\hline 300.8 & - & - & $7.1 \pm 0.3$ & $11.2 \pm 1.4$ \\
\hline 320.6 & $6.2 \pm 0.3$ & $7.1 \pm 1.3$ & - & - \\
\hline 335.6 & $9.7 \pm 0.3$ & $11.6 \pm 4.6$ & - & - \\
\hline 349.6 & $15.8 \pm 2.7$ & $19.3 \pm 7.2$ & - & - \\
\hline
\end{tabular}

The results reported in Table 2 show that the rate constants of the reversible transalkylation of $\mathbf{2 E t}_{2}$ are notably larger than those measured for irreversible hafnocene ethylations. For example, at $300 \mathrm{~K}$ the reversible ethyl exchange with $\mathrm{ZnEt}_{2}$ is four orders of magnitude faster than the methyl to ethyl exchange of $\mathbf{1 M e}_{2}$. Moreover, transalkylation of the two ethyl groups in syn and anti positions occurs essentially with the same reaction rate, indicating that the process is not diastereoselective. The behavior of $\mathrm{AlEt}_{3}$ and $\mathrm{ZnEt}_{2}$ is not markedly different; for example, at $300 \mathrm{~K}$ rate constant values measured with $\mathrm{AlEt}_{3}$ are only 2-3 times larger than those obtained with $\mathrm{ZnEt}_{2}$.

The Eyring analysis of average transalkylation rate constants (Supporting Information) provided an activation enthalpy of $6.3 \pm 0.3 \mathrm{kcal} / \mathrm{mol}$ for $\mathrm{ZnEt}_{2}$ and $8.1 \pm 0.3 \mathrm{kcal} / \mathrm{mol}$ for $\mathrm{AlEt}_{3}$. For the activation entropy, values of $-35 \pm 2$ and $-27 \pm 2 \mathrm{cal} \cdot \mathrm{mol} / \mathrm{K}$ were obtained for $\mathrm{ZnEt}_{2}$ and $\mathrm{AlEt}_{3}$, respectively.

The effect of $\mathrm{AlEt}_{3}$ concentration was explored by performing ${ }^{1} \mathrm{H}$ EXSY NMR experiments at different concentrations of hafnium complex and $\mathrm{AlEt}_{3}$ keeping their molar ratio constant, in order to induce the full conversion of $\mathbf{2} \mathbf{M e}_{2}$ and $\mathbf{2 M e E t}$ to $\mathbf{2} \mathbf{E t}_{\mathbf{2}}$. The results showed that, for $\mathbf{2} \mathbf{E t}_{\mathbf{2}}$ at a concentration of $9.5 \mathrm{mM}$, average rate constants of reversible transalkylation were only 2 times larger than those measured at $34.0 \mathrm{mM}$ (Figure 5). The Eyring analysis of such data allowed a $\Delta \mathrm{H}^{\ddagger}$ of $7.5 \pm 0.3$ $\mathrm{kcal} / \mathrm{mol}$ and a $\Delta \mathrm{S}^{\neq}=-28 \pm 3 \mathrm{cal} \cdot \mathrm{mol} / \mathrm{K}$ to be derived (Supporting Information).

When $\mathbf{2} \mathbf{M e}_{2}$ was mixed with 1 equivalent of $\mathrm{AlEt}_{3}$ and 10 equivalents of $\mathrm{ZnEt}_{2}$, the trend of rate constants was similar to that obtained for pure $\mathrm{ZnEt}_{2}$ (Figure 5). For example, the average rate constant measured at $300 \mathrm{~K}$ is $4.2 \mathrm{M}^{-1} \mathrm{~s}^{-1}$, while that of pure $\mathrm{ZnEt}_{2}$ is $3.3 \mathrm{M}^{-1} \mathrm{~s}^{-1}$ at the same temperature. 


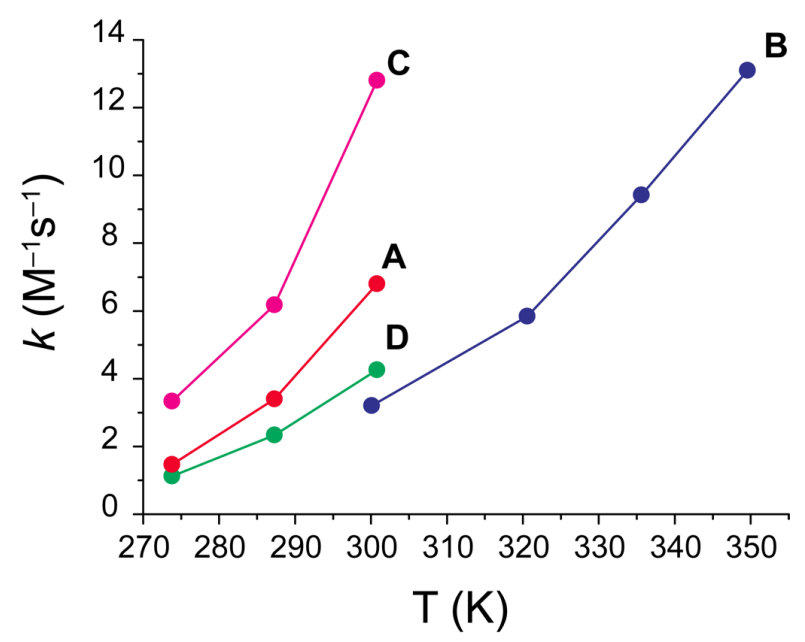

Figure 5. Second order rate constants $\left(k, \mathrm{M}^{-1} \mathrm{~s}^{-1}\right)$ for reversibile transalkylation of $\mathbf{2} \mathbf{E t}_{2}$ with $\mathrm{AlEt}_{3}(\mathrm{~A}$ : $\left.\mathrm{C}_{\mathrm{Hf}}=34.0 \mathrm{mM}, \mathrm{Al} / \mathrm{Hf}=5 ; \mathrm{C}: \mathrm{C}_{\mathrm{Hf}}=9.5 \mathrm{mM}, \mathrm{Al} / \mathrm{Hf}=5\right), \mathrm{ZnEt}_{2}\left(\mathrm{~B}: \mathrm{C}_{\mathrm{Hf}}=34.0 \mathrm{mM}, \mathrm{Zn} / \mathrm{Hf}=6\right)$ and their mixture (D: $\left.\mathrm{C}_{\mathrm{Hf}}=37.9, \mathrm{Zn} / \mathrm{Al} / \mathrm{Hf}=10: 1: 1\right)$ in toluene- $d_{8}$.

To summarize, it was shown that $\mathbf{2 E t}_{\mathbf{2}}$ undergoes fast and reversible ethyl exchange with $\mathrm{ER}_{\mathrm{n}}$. Contrary to what observed for cationic species, ${ }^{16}$ cyclometalated naphthyl group does not give ligand exchange with $\mathrm{Al} / \mathrm{Zn}$ alkyls, suggesting that a coordinative vacancy is necessary to promote the breakage of the Hf-aryl bond. The free activation energy at $298 \mathrm{~K}$ for reversible ethyl exchange is close to $16.0 \mathrm{kcal} / \mathrm{mol}$ for both the alkylating agents. The activation barrier is composed of a large and negative activation entropy ( -27 and $-35 \mathrm{cal} \cdot \mathrm{mol} / \mathrm{K}$ for $\mathrm{AlEt}_{3}$ and $\mathrm{ZnEt}_{2}$, respectively) and a modest activation enthalpy ( 8.1 and $6.3 \mathrm{kcal} / \mathrm{mol}$ for $\mathrm{AlEt}_{3}$ and $\mathrm{ZnEt}_{2}$, respectively). $\Delta \mathrm{S}^{\ddagger}$ values suggest an associative mechanism in which the alkyl is exchanged through the formation of a heterobimetallic adduct at the transition state, as previously inferred above for $\mathbf{1} \mathbf{M e}_{2}$. Also in the present case, $\Delta \mathrm{S}^{\neq}$values measured for $\mathrm{AlEt}_{3}$ and $\mathrm{ZnEt}_{2}$ are not markedly different thus indicating that the dissociation/recombination process of $\mathrm{AlEt}_{3}$ is not rate determining. Higher values of activation enthalpy were obtained for $\mathrm{AlEt}_{3}$ $\left(\Delta \Delta \mathrm{H}^{\neq}=1.8 \mathrm{kcal} / \mathrm{mol}\right)$, in contrast to those observed with $\mathbf{1} \mathbf{M e}_{2}$. This could be due to the higher Lewis acidity of the $\mathrm{Hf}$ atom in the pyridylamido complex that prevents the dimerization with $\mathrm{AlEt}_{3}$ through the establishment of bridging interactions. In such a mechanistic scenario, the more electron-rich $\mathrm{ZnEt}_{2}$ could be favored in the interaction with the postmetallocene complex and undergo transalkylation with a lower activation enthalpy.

\section{Metallocenium species/ER $\mathbf{n}$ mixtures}

The reactivity of cationic hafnocenes with $\mathrm{ER}_{\mathrm{n}}$ was explored using both mononuclear $\left[\mathrm{Cp}_{2} \mathrm{HfMe}\right]\left[\mathrm{B}\left(\mathrm{C}_{6} \mathrm{~F}_{5}\right)_{4}\right]$ and binuclear $\left[\left(\mathrm{Cp}_{2} \mathrm{HfMe}\right)_{2}(\mu-\mathrm{Me})\right]\left[\mathrm{B}\left(\mathrm{C}_{6} \mathrm{~F}_{5}\right)_{4}\right][\mathbf{1}(\boldsymbol{\mu}-\mathbf{M e}) \mathbf{1}]$ ion pairs, which can be straightforwardly obtained by reacting $\mathbf{1} \mathbf{M e}_{2}$ with 1 or 0.5 equivalents of $\left[\mathrm{CPh}_{3}\right]\left[\mathrm{B}\left(\mathrm{C}_{6} \mathrm{~F}_{5}\right)_{4}\right]$, respectively. The mononuclear ion pair quickly underwent $-\mathrm{C}_{6} \mathrm{~F}_{5}$ transfer reactions, especially when $\mathrm{Zn}$ al- 
kyls were used. Therefore, the attention was focused on $\mathbf{1}(\mu-\mathbf{M e}) \mathbf{1}$ that, despite it is not likely relevant under polymerization conditions, allowed us to probe collateral reactions occurring at the metal center and tendency of $\mathrm{ER}_{\mathrm{n}}$ to split hafnocenium dimers.

a) Reactions with AlMe $_{3}$. When a 10-fold excess of $\mathrm{AlMe}_{3}$ was added to a solution of $\mathbf{1}(\mu-\mathrm{Me}) \mathbf{1}$ in toluene- $d_{8}$, the ${ }^{1} \mathrm{H}$ NMR spectrum of the reaction mixture showed the immediate consumption of the starting hafnium complex and the concomitant formation of two new species in a 1:1 ratio that were assigned to $\mathbf{1} \mathbf{M e}_{2}$ and $\left[\mathrm{Cp}_{2} \mathrm{Hf}\left(\mu-\mathrm{Me}_{2} \mathrm{AlMe}_{2}\right]\left[\mathrm{B}\left(\mathrm{C}_{6} \mathrm{~F}_{5}\right)_{4}\right]^{9 \mathrm{f}}[\mathbf{1}(\boldsymbol{\mu}-\mathbf{M e}) \mathrm{Al}]\right.$. The ${ }^{1} \mathrm{H}$ NOESY NMR spectrum of the reaction mixture (Figure 6a) revealed the presence of a selective pattern of chemical exchange involving: $i$ ) the cyclopentadienyl rings of both neutral and ionic metallocenes, ii) the methyl groups of $\mathbf{1} \mathbf{M e}_{2}$ and the brigding ones of $\mathbf{1}(\mu-\mathbf{M e}) \mathbf{A l}$, iii) the terminal methyl moieties of $\mathbf{1}(\mu-\mathbf{M e}) \mathbf{A l}$ and free $\mathrm{AlMe}_{3}$. In line with previous observations, ${ }^{25}$ no exchange was detected between terminal and bridging methyl groups of the bimetallic cation in the 298-338 K temperature range, thus indicating that the $\mathrm{AlMe}_{3}$ dissociation/recombination in $\mathbf{1}(\mu-\mathrm{Me}) \mathbf{A l}$ is very slow (or frozen). Further evidence of this was obtained from a ${ }^{19} \mathrm{~F},{ }_{1}^{1} \mathrm{H}$ HOESY NMR experiment, which showed the presence of dipolar contacts between the fluorine atoms of the borate anion and the methyl groups of $\mathbf{1} \mathbf{M e} \mathbf{e}_{\mathbf{2}}$ (Figure 6b) likely due to transferred Overhauser Effect. ${ }^{26}$
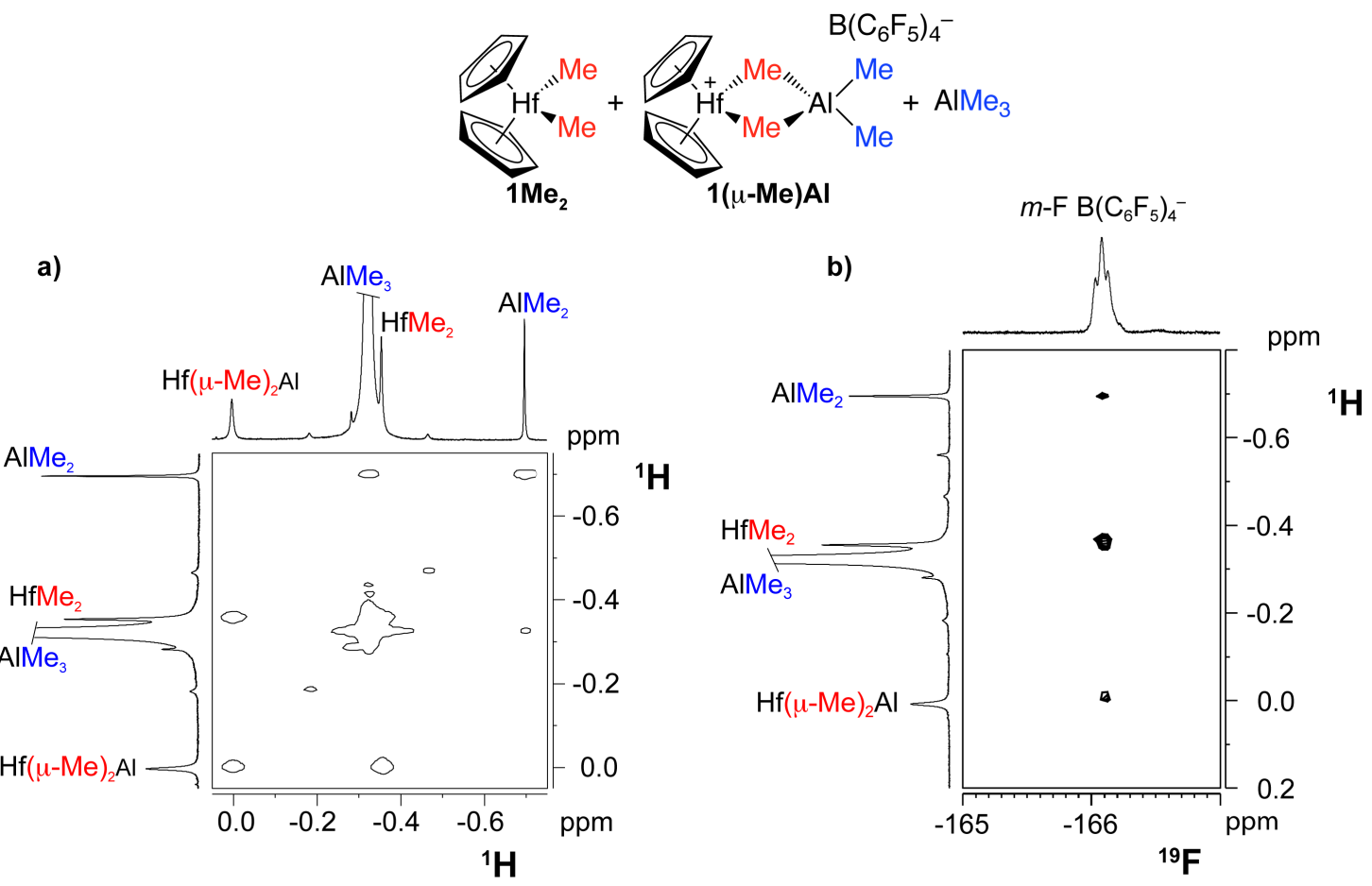

Figure 6. a) A section of the ${ }^{1} \mathrm{H}$ NOESY NMR spectrum of a toluene- $d_{8}$ solution containing $\mathbf{1} \mathbf{M e}_{2}$, $\mathbf{1}\left(\boldsymbol{\mu}\right.$-Me)Al and $\left.\mathrm{AlMe}_{3} ; \mathrm{b}\right)$ a section of the ${ }^{19} \mathrm{~F},{ }^{1} \mathrm{H}$ NOESY NMR spectrum of the same mixture.

The timescale of fluxionality was suitable for VT ${ }^{1} \mathrm{H}$ EXSY NMR experiments and kinetic rate constants were determined by applying a two-site exchanging model. ${ }^{24}$ The results are reported in 
Table 3 and show that the exchange of hafnium methyl groups occurs roughly 20 times faster than those of aluminum along the explored temperature range. The Eyring analysis of the data afforded $\Delta \mathrm{H}^{\ddagger}$ values of $13.7 \pm 1.0$ and $14.1 \pm 1 \mathrm{kcal} / \mathrm{mol}$ for the $\mathrm{Hf}-\mathrm{Me}$ and $\mathrm{Al}-\mathrm{Me}$ exchanges, respectively, while $\Delta \mathrm{S}^{ \pm}$values of $-8 \pm 1$ and $-14.0 \pm 1 \mathrm{cal} \cdot \mathrm{mol} / \mathrm{K}$ were obtained.

Formally, the observed dynamic process suggests that $\left[\mathrm{AlMe}_{2}\right]\left[\mathrm{B}\left(\mathrm{C}_{6} \mathrm{~F}_{5}\right)_{4}\right]$ ion pairs ${ }^{27,28}$ are exchanged between neutral and ionic metallocenes. The obtained activation entropy values indicate that the reaction occurs via associative interchange, likely through the attack of $\mathbf{1} \mathbf{M e}_{2}$ at the $\mathrm{Al}$ atom of the bimetallic $\mathbf{1}(\mu-\mathrm{Me}) \mathbf{A l}$ ion pair; the same conclusion applies to the exchange with $\mathrm{AlMe}_{3}$, for which similar $\Delta \mathrm{H}^{\ddagger}$ and $\Delta \mathrm{S}^{\ddagger}$ were obtained. Activation enthalpy values are rather high for both processes and similar to those obtained in the case of the ethyl exchange on neutral hafnocenes, indicating that such processes are still difficult on cationic species, presumably due to the strong $\mathrm{AlMe}_{3}-$ hafnocene bridging interaction and the large Hf-Me bonding energy.

Table 3. Rate constants $\left(\mathrm{M}^{-1} \mathrm{~s}^{-1}\right)$ for $\mathbf{1} \mathbf{M e}_{2} / \mathbf{1}\left(\mu\right.$-Me)Al $\left(k_{1}\right)$ and $\mathbf{1}\left(\boldsymbol{\mu}\right.$-Me)Al $/ \mathrm{AlMe}_{3}\left(k_{2}\right)$ reversible exchanges as a function of temperature $(\mathrm{T}, \mathrm{K})$.

\begin{tabular}{|c|c|c|}
\hline $\mathrm{T}$ & $k_{1}$ & $k_{2}$ \\
\hline 298 & $(8.1 \pm 0.8)$ & $(0.2 \pm 0.1)$ \\
\hline 308 & $(20.0 \pm 2.0)$ & $(0.8 \pm 0.2)$ \\
\hline 318 & $(42.6 \pm 0.2)$ & $(1.3 \pm 0.1)$ \\
\hline 328 & $(74.2 \pm 0.4)$ & $(2.6 \pm 0.1)$ \\
\hline 338 & $(152.0 \pm 3.0)$ & $(4.9 \pm 0.1)$ \\
\hline
\end{tabular}

b) Reactions with $\mathbf{Z n M e}_{2}$. Upon mixing a solution of $\mathbf{1}(\mu-\mathrm{Me}) \mathbf{1}$ in toluene- $d_{8}$ with 5 equivalents of $\mathrm{ZnMe}_{2}$, no sign of reaction was observed in the ${ }^{1} \mathrm{H}$ NMR spectrum thus suggesting that $\mathrm{ZnMe}_{2}$ has a lower tendency to split the hafnium dimer than that of $\mathrm{AlMe}_{3}$. In addition, no signs of reversible methyl exchange were detected in the ${ }^{1} \mathrm{H}$ EXSY NMR spectra. After 2 days at room temperature, the starting homobimetallic ion pair was consumed to give $\mathbf{1} \mathbf{M e}_{2}, \mathrm{CH}_{4}$ and two new hafnium compounds (a and $\mathbf{b}$ ) in approximately 1:1 ratio. The latter have three signals each: one signal for $\mathrm{Cp}$ resonances located at $\delta_{\mathrm{H}}=5.54$ and $5.21 \mathrm{ppm}\left(\delta_{\mathrm{C}}=111.1\right.$ and $\left.109.9 \mathrm{ppm}\right)$, a singlet for $\mathrm{Hf}-\mathrm{CH}_{2}$ moieties at $\delta_{\mathrm{H}}=0.13$ and $1.85 \mathrm{ppm}\left(\delta_{\mathrm{C}}=68.9\right.$ and $\left.65.3 \mathrm{ppm}\right)$ and a signal for $\mathrm{Hf}-\mathrm{CH}_{3}$ groups at $\delta_{\mathrm{H}}=-0.35$ and -0.42 $\operatorname{ppm}\left(\delta_{\mathrm{C}}=25.8\right.$ and $\left.36.1 \mathrm{ppm}\right)$; the relative signal intensities were 20:2:6 and 10:2:3 for a and $\mathbf{b}$, respectively. By monitoring the composition of the reaction mixture as a function of time, it was observed that $\mathbf{a}$ formed initially to reach a steady state concentration, while the concentration of $\mathbf{b}$ increased as the starting ion pair decreased. ${ }^{1} \mathrm{H}$ NOE experiments showed the presence of rather strong dipolar contacts between $\mathrm{Cp}$ signals and both methyl and methylene resonances of the two species (Supporting Information). In addition, a NOE interaction was detected between methyl and methylene signals of a while, in the case of $\mathbf{b}$, the interaction was notably weaker. 
It is possible to hypothesize that the presence of $\mathbf{1} \mathbf{M e}_{\mathbf{2}}$ in the reaction mixture arose from the splitting of the starting bimetallic cation, while the formation of $\mathrm{Hf}_{-} \mathrm{CH}_{2}$ moieties and the evolution of methane suggest that a $\sigma$-bond metathesis of $\mathrm{Hf}-\mathrm{Me}$ groups occurred. By compiling all the pieces of information, it can be speculated that a corresponds to a bimetallic dimer featuring a $\mathrm{CH}_{2} \mathrm{ZnMe}$ moiety, while b could be labeled as a monomeric $\left[\mathrm{Cp}_{2} \mathrm{Hf}\left(\mathrm{CH}_{2} \mathrm{ZnMe}\right)\right]\left[\mathrm{B}\left(\mathrm{C}_{6} \mathrm{~F}_{5}\right)_{4}\right]$ fragment. The ${ }^{13} \mathrm{C}$ chemical shift value of the methyl group in $\mathbf{b}$ suggests the presence of an interaction between the $\mathrm{Zn}-\mathrm{Me}$ moiety and the Hf atom. An higher amount of $\mathbf{b}$ was obtained by using a larger amount of $\mathrm{ZnMe}_{2}(20$ equivalents), suggesting that it is likely formed from the breakage of the dimeric species a. No traces of dynamic processes were observed in the NOE spectrum, indicating that no reversible alkyl exchange occurs in the EXSY timescale.

c) Reactions with $\boldsymbol{E}(\boldsymbol{E} \boldsymbol{t})_{n}$. When $\mathbf{1}(\boldsymbol{\mu}-\mathrm{Me}) \mathbf{1}$ was mixed in toluene- $d_{8}$ with an excess of $\mathrm{ZnEt}_{2}$ at $283 \mathrm{~K}$, ${ }^{1} \mathrm{H}$ NMR spectroscopy revealed the complete disappearance of the starting ion pair with the formation of $\mathbf{1 E t _ { 2 }}$ and other cationic products. The integration of the spectra indicated that all the methyl groups of the starting $\mathbf{1}(\mu-\mathrm{Me}) \mathbf{1}$ were converted into $\mathrm{ZnMe}_{2}$, suggesting a fast and irreversible ethyl transfer to hafnocene. The reaction mixture was unstable under these conditions and $\mathbf{1 E t}_{2}$ was consumed in a further process where ethane and a new species formed. The ${ }^{1} \mathrm{H}$ NMR spectrum showed the presence of four $\mathrm{Cp}$ resonances $\left(\delta_{\mathrm{H}}=5.23,5.02,4.94\right.$ and $\left.4.79 \mathrm{ppm}\right)$, an $\mathrm{ABX}$ spin system (three doublets of doublets at $\delta_{\mathrm{H}}=3.43,3.03$ and $1.40 \mathrm{ppm}, \mathrm{J}_{\mathrm{HH}}=17.0,12.0$ and $3.5 \mathrm{~Hz}$ ) and a markedly shielded methyl group $\left(\delta_{\mathrm{H}}=-2.13 \mathrm{ppm}\right)$. The $\mathrm{ABX}$ spin system was identified as a $-\mathrm{CH}-\mathrm{CH}_{2}$ moiety by means of ${ }^{1} \mathrm{H},{ }^{13} \mathrm{C}$ HSQC NMR spectrum and showed a $\delta_{\mathrm{C}}=122.1$ and $\delta_{\mathrm{C}}=59.5 \mathrm{ppm}$ for methyne and methylene moieties, respectively. The rather high chemical shift value of the $\mathrm{CH}$ moiety lead us to hypothesize the formation of a methyne-bridged bimetallic dimer, likely arising from a double $\sigma$-bond metathesis reaction of Hf-ethyl groups (Scheme 5). ${ }^{1} \mathrm{H}$ NOESY NMR experiments (Supporting Information) indicating the presence of selective dipolar interactions between the $\mathrm{CHCH}_{2}$ moiety and the four magnetically non-equivalent cyclopentadienyl groups. The nature of methyl group located at $\delta_{\mathrm{H}}=-2.13 \mathrm{ppm}$, having a ${ }^{13} \mathrm{C}$ chemical shift at $\delta_{\mathrm{C}}=7.0 \mathrm{ppm}$, is unclear. Given that the latter showed strong NOE contacts only with the $\mathrm{Cp}$ rings, it can be speculated that it belongs to an anionic methylzincate fragment undergoing ion pairing with the bimetallic cation. 


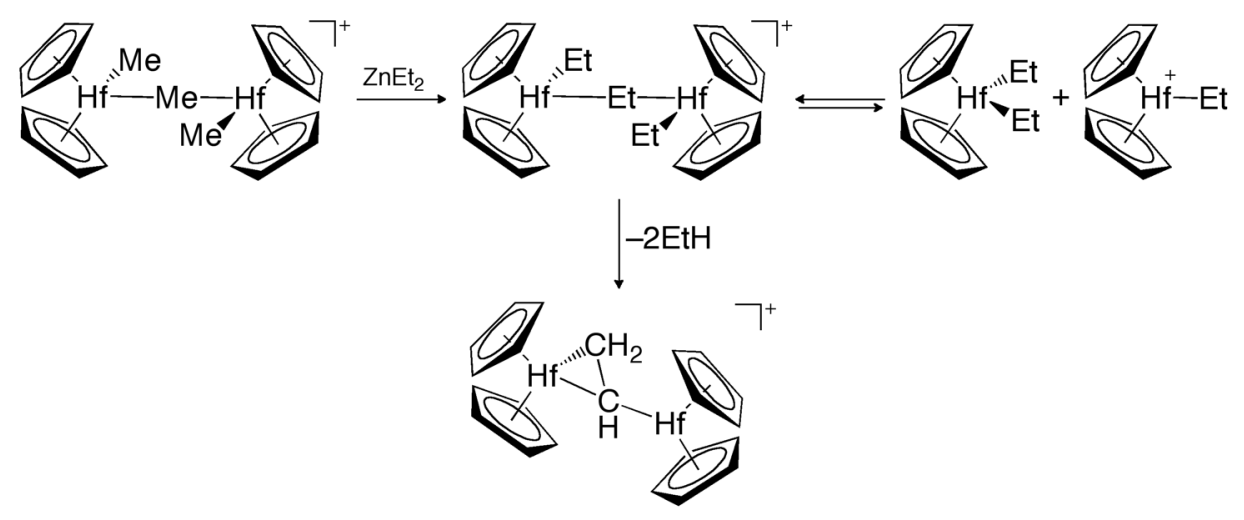

Scheme 5. Proposed reactivity of $\mathbf{1}(\mu-\mathrm{Me}) \mathbf{1}$ with $\mathrm{ZnEt}_{2}$.

When the reaction was performed with $\mathrm{AlEt}_{3}$, a similar pathway was observed. At the end of the reaction, the ${ }^{1} \mathrm{H}$ NMR spectrum showed the presence of many products and two ABX spin systems (80:20 ratio) were observed. For the latter, ${ }^{1} \mathrm{H}$ and ${ }^{13} \mathrm{C}$ NMR chemical shift values were rather different to those obtained with $\mathrm{ZnEt}_{2}$ : the first pattern had $\delta_{\mathrm{H}}=3.22,0.70,0.32 \mathrm{ppm}$ and $\delta_{\mathrm{C}}=70.5,25.4 \mathrm{ppm}$ while the second had $\delta_{\mathrm{H}}=3.10,0.94,0.50 \mathrm{ppm}$ and $\delta_{\mathrm{C}}=69.8,25.2 \mathrm{ppm}$. Assuming that the same bimetallic cation observed before formed, it can be inferred that the high low-frequency shift of the ${ }^{13} \mathrm{C}$ NMR resonances of the ABX spin system is due to bridging interactions with the excess of $\mathrm{AlR}_{3}$ species.

Once again, no chemical exchange between any metallocene species and Al/Zn alkyls was observed, indicating that no reversible alkyl transfer occurs between hafnium and the main group metal and that $\sigma$-bond metathesis is the main active deactivation pathway. This seems to be in agreement with the general tendency of cationic hafnocenes to undergo bond methatesis with different substrates. $^{29}$

\section{Hafnium pyridylamido cationic species}

Cationic species derived by the activation of $2 \mathbf{M e}_{2}$ with $\left[\mathrm{CPh}_{3}\right]\left[\mathrm{B}\left(\mathrm{C}_{6} \mathrm{~F}_{5}\right)_{4}\right]$ are known to undergo ligand exchange reactions with $\mathrm{ZnR}_{2}$ or $\mathrm{AlEt}_{3}$ at low temperature, affording heterobimetallic adducts in which the naphtyl group acts as a bridge between Hf and the main group metal. ${ }^{16}$ To investigate the thermal transformation of such species, a sample of the heterobimetallic adduct with $\mathrm{ZnMe}_{2}$ was synthesized in toluene- $d_{8}$ and kept at room temperature for 12 hours. The ${ }^{1} \mathrm{H}$ NMR spectrum of the solution obtained (Supporting Information) showed the presence of a prevalent set of sharp signals featuring typical fingerprints of pyridylamido hafnium complexes and a broad singlet at $\delta_{\mathrm{H}}=0.73 \mathrm{ppm}$. The latter was assigned to $\mathrm{BMe}_{3}$, reasonably arising from $-\mathrm{C}_{6} \mathrm{~F}_{5}$ transfer reactions between $\mathrm{ZnMe}_{2}$ and the anion. ${ }^{28,30}$ In agreement, the ${ }^{19} \mathrm{~F}$ NMR spectrum showed the disappearance of starting borate resonances with the formation of many sets of signals that were assigned to $\mathrm{Zn}\left(\mathrm{C}_{6} \mathrm{~F}_{5}\right)_{2}\left(\delta_{\mathrm{F}}=118.4,-153.4\right.$ and $-160.9 \mathrm{ppm})^{30}$ and $\mathrm{Hf}-\mathrm{C}_{6} \mathrm{~F}_{5}$ moieties (ortho fluorine at $\delta_{\mathrm{F}}=119.4,-121.5$, accounting for two $\mathrm{F}$ 
atoms, and $-125.5 \mathrm{ppm}) .{ }^{14 b, 31}$ The latter signals showed selective NOE interactions with pyridylamido protons in the ${ }^{19} \mathrm{~F},{ }^{1} \mathrm{H}$ HOESY NMR spectrum, thus confirming that two $\mathrm{C}_{6} \mathrm{~F}_{5}$ rings are bound to the same hafnium atom. Therefore, the complete $-\mathrm{C}_{6} \mathrm{~F}_{5}$ ring transfer to zinc and hafnium atoms (Scheme 6) led to the complete decomposition of borate anion and neutralization of pyridylamido cation. In perfect agreement with the latter hypothesis, a ${ }^{13} \mathrm{C}$ NMR signal at $\delta_{\mathrm{C}}=209.3 \mathrm{ppm}$, showing long-range scalar correlations with naphthyl protons (Supporting Information), was observed thus confirming that the remetalation of the napthyl group occurred.

Interestingly, when $\mathbf{2 M e}_{2}$ was activated with $\left[\mathrm{HNMe}_{2} \mathrm{Ph}\right]\left[\mathrm{B}\left(\mathrm{C}_{6} \mathrm{~F}_{5}\right)_{4}\right]$ to give the dimethyl cation featuring the demetalated naphthyl group ${ }^{14 \mathrm{~b}}$ and then reacted with $\mathrm{ZnMe}_{2}$, no reaction took place at room temperature and $\mathrm{B}\left(\mathrm{C}_{6} \mathrm{~F}_{5}\right)_{4}{ }^{-}$did not decompose. Reversible methyl transfer between $\mathrm{Zn}$ and $\mathrm{Hf}$ atoms was shown to occur, but the superimposed methyl groups hampered the quantification of the rate constants by ${ }^{1} \mathrm{H}$ EXSY NMR spectroscopy.

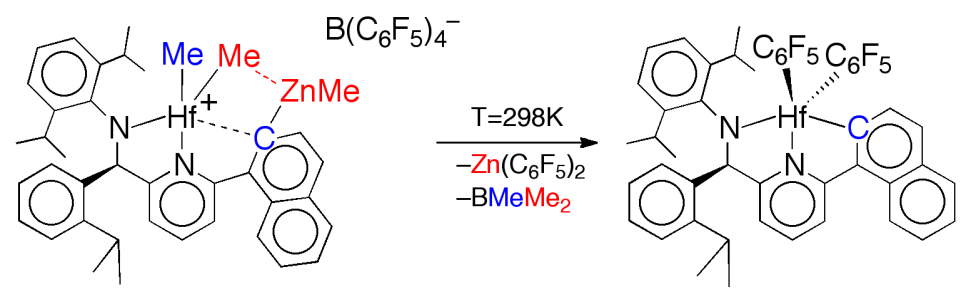

Scheme 6. Thermal evolution of pyridylamidoHfMe/ $/ \mathrm{ZnMe}_{2}$ adducts.

In the case of the adduct with $\mathrm{AlMe}_{3}$, the thermal transformation at room temperature was more complex and led to the formation of two prevalent species in a 1:1 ratio, as deduced by the presence of 6 septets due to isopropyl groups in the ${ }^{1} \mathrm{H}$ NMR spectrum. The ${ }^{19} \mathrm{~F}$ NMR spectrum showed the appearance of both Al- and $\mathrm{Hf}-\mathrm{C}_{6} \mathrm{~F}_{5}$ moieties that, together with the presence of $\mathrm{BMe}_{3}$ in the ${ }^{1} \mathrm{H}$ NMR spectrum, confirmed borate anion decomposition. Different to what was observed with $\mathrm{ZnMe}_{2}$, an accurate analysis of the long range interactions in the ${ }^{1} \mathrm{H},{ }^{13} \mathrm{C}$ HMQC spectrum revealed that no remetalation of the naphthyl occurred. The first product showed two doublets located at $\delta_{\mathrm{H}}=4.60$ and $0.98 \mathrm{ppm}\left({ }^{3} \mathrm{~J}_{\mathrm{HH}}=7.8 \mathrm{~Hz}, \delta_{\mathrm{C}}=74.1 \mathrm{ppm}\right)$ and a Al-Me group falling at $\delta_{\mathrm{H}}=-0.88 \mathrm{ppm}$. A ${ }^{19} \mathrm{~F},{ }^{1} \mathrm{H}$ HOESY NMR spectrum showed that such resonances had selective NOE interactions with one ortho-F atom belonging to a $\mathrm{Hf}-\mathrm{C}_{6} \mathrm{~F}_{5}$. The second product showed the presence of an $\mathrm{Hf}-\mathrm{Me}$ group at $\delta_{\mathrm{H}}=1.72 \mathrm{ppm}$ $\left(\delta_{\mathrm{C}}=69.5 \mathrm{ppm}\right)$ that was dipolarly coupled with another ortho-F of an $\mathrm{Hf}_{-} \mathrm{C}_{6} \mathrm{~F}_{5}$ moiety. Full characterization of the complex was hampered by the overlapping of many signals but it was possibile to conclude that aluminium has no tendency to detach from the naphthyl group, opening the route for new deactivation pathways including the formation of bridging $\mathrm{Hf}-\mathrm{CH}_{2}-\mathrm{Al}$ moieties arising from $\sigma$-bond metathesis.

\section{Conclusions}


The reactions of organometallic $\mathrm{Hf}(\mathrm{IV})$ complexes with $\mathrm{ZnR}_{2}$ and $\mathrm{AlEt}_{3}(\mathrm{R}=\mathrm{Me}$ or Et) have been explored by means of NMR spectroscopy, with the main purpose of obtaining insights into alkyl transfer processes that are central to coordinative chain transfer olefin polymerization catalysis. The simplest hafnocene $\mathbf{1} \mathbf{M e}_{2}$ and highly-optimized pyridylamido $\mathbf{2} \mathbf{M e}_{2}$ have been chosen as a case study, in order to contrast a poorly performing metallocene and an industrially relevant post-metallocene featuring the same transition metal. The main conclusion of this work is that the efficiency of the chain transfer is not arising from the nature of the single transition or main group metal complex, but reflects the matching between them. The investigation of the reactivity of neutral dimethyl species with $E_{n}$ revealed that the ancillary ligand plays a remarkable role in determining both rate and reversibility of alkyl exchange between hafnium and main metal. In fact, metallocene reacts slowly with both $\mathrm{ZnEt}_{2}$ and $\mathrm{AlEt}_{3}$ to give methyl to ethyl exchange, while postmetallocene reacts much faster and reversibly. Variable temperature kinetic studies relate this difference to the notably lower activation enthalpy of the reaction with $\mathbf{2} \mathbf{E t}_{2}\left(\Delta \Delta \mathrm{H}^{\neq}=8 \mathrm{kcal} / \mathrm{mol}\right.$ with $\left.\mathrm{ZnEt}_{2}\right)$ whereas activation entropy values have shown to be large and negative in all the cases, pointing to an associative reaction mechanism. The nature of chain transfer agent was found to be important only in the case of metallocene ethylation, where the alkyl transfer occurs out of the equilibrium. In this case, $\mathrm{AlEt}_{3}$ reacts faster than $\mathrm{ZnEt}_{2}$ due to a lower $\Delta \mathrm{H}^{\ddagger}$ value. On the contrary, pyridylamido precatalysts undergo fast and reversible alkyl exchange with both $\mathrm{Al}-$ and $\mathrm{Zn}$ - alkyls with comparable activation barriers, reasonably due to the combination of higher Lewis acidity and less steric encumbrance at the metal centre in postmetallocene framework.

As far as cationic species are concerned, homobimetallic $\mathbf{1}(\mu-\mathrm{Me}) \mathbf{1}$ ion pair reacts with $\mathrm{ER}_{\mathrm{n}}$ affording different products whose structure depends on the nature of both $\mathrm{E}$ and $\mathrm{R}$. In the case of $\mathrm{AlMe}_{3}$, the bimetallic cation is readily split into $\mathbf{1} \mathbf{M e}_{2}$ and heterobimetallic $\mathbf{1}(\boldsymbol{\mu}-\mathbf{M e}) \mathbf{A l}$ ion pair, which have been found to undergo slow selective chemical exchange formally due to $\left[\mathrm{AlMe}_{2}\right]\left[\mathrm{B}\left(\mathrm{C}_{6} \mathrm{~F}_{5}\right)_{4}\right]$ ion pairs transfer. $\mathrm{ZnMe}_{2}$ is instead less electrophilic and does not favor the cleavage of the bimetallic cation. However, it stimulates a very slow $\sigma$-bond metathesis reaction leading to the formation of methane and $\mathrm{Hf}-\mathrm{CH}_{2}-\mathrm{Zn}$ moieties. In the case of $\mathrm{ZnEt}_{2}$ and $\mathrm{AlEt}_{3}$, a fast irreversible ethylation of the bimetallic cation occurs but, even at low temperature, rapid metathesis reactions affording ethane and methyne-bridged bimetallic cations take place. Interestingly, none of the formed species exhibit reversible chemical exchange with $\mathrm{ER}_{\mathrm{n}}$, indicating that this kind of process is still difficult for cationic hafnocenes. Heterobimetallic [pyridylamido(Hf)Me $\left.(\mu-\mathrm{Me}) \mathrm{EMe}_{\mathrm{n}-1}\right]\left[\mathrm{B}\left(\mathrm{C}_{6} \mathrm{~F}_{5}\right)_{4}\right]$ adducts showed rapid decomposition of the borate anion to $\mathrm{BMe}_{3}$ as main deactivation pathway. Interestingly, remetalation of the naphthyl group on the Hf atom was observed when $\mathrm{E}=\mathrm{Zn}$. This strongly supports that the formation of heterobimetallic adducts with $\mathrm{Zn}$ is a reversible reaction, as previously suggested. ${ }^{16}$ In the case of the adduct with $\mathrm{Al}$, no remetalation occurs and other decomposition pathways take place leading to the formation of $\mathrm{Al}-\mathrm{CH}_{2}-\mathrm{Hf}$ moieties.

\section{Experimental Section}


Materials and methods. All manipulations of air-sensitive materials were performed in flamed Schlenk glassware on a Schlenk line, interfaced to a high-vacuum pump $\left(10^{-5} \mathrm{mmHg}\right)$, or in a nitrogen-filled Vac-Atmosphere glovebox with a high capacity recirculator $\left(<1 \mathrm{ppm}_{2}\right.$ and $\left.\mathrm{H}_{2} \mathrm{O}\right)$. All solvents were preventively distilled after $12 \mathrm{~h}$ reflux over $\mathrm{Na}$ and freeze-pump-thaw degassed over $\mathrm{Na} / \mathrm{K}$ alloy. Benzene- $d_{6}$ and toluene- $d_{8}$ were freeze-pump-thaw degassed over $\mathrm{Na} / \mathrm{K}$ alloy, vacuum transferred into a Schlenk flask with a PTFE valve and stored over activated molecular sieves.

Bis-cyclopentadienyl-hafnium-dimethyl $\left(\mathbf{1 M e}_{2}\right)$ was purchased from Strem Chemicals and used as received. [N-[2,6-Diisopropylphenyl]- $\alpha$-[2-isopropylphenyl]-6-(1-naphthalenyl)-2pyridinemethanaminato]hafnium dimethyl $\left(\mathbf{2} \mathbf{M e}_{2}\right)$ was obtained as a gift from Dow Chemical and was used as received. $\left[\mathrm{CPh}_{3}\right]\left[\mathrm{B}\left(\mathrm{C}_{6} \mathrm{~F}_{5}\right)_{4}\right]$ was obtained from Boulder Scientific and used as received. $\mathrm{ZnMe}_{2}$ (2.0 M solution in toluene), $\mathrm{ZnEt}_{2}$ (Zn 52\% wt.), $\mathrm{AlMe}_{3}$ (97\%) and $\mathrm{AlEt}_{3}$ (93\%) were purchased from Sigma Aldrich and used as received. CAUTION: tri-alkylaluminum and dialkyl-zinc are pyrophoric and must be handled in rigorously dry conditions.

${ }^{1} \mathrm{H},{ }^{1} \mathrm{H}$ inversion recovery, ${ }^{13} \mathrm{C}\left\{{ }^{1} \mathrm{H}\right\},{ }^{1} \mathrm{H}$ COSY, ${ }^{1} \mathrm{H}$ NOESY, ${ }^{1} \mathrm{H}$ EXSY, ${ }^{1} \mathrm{H},{ }^{13} \mathrm{C}$ HMQC $,{ }^{1} \mathrm{H},{ }^{13} \mathrm{C}$ HSQC, ${ }^{1} \mathrm{H},{ }^{13} \mathrm{C}$ HMBC, ${ }^{19} \mathrm{~F}$ and ${ }^{19} \mathrm{~F},{ }^{1} \mathrm{H}$ HOESY NMR experiments were performed on a Bruker Avance DRX 400 equipped with a QNP probe or on a Bruker Avance III 400 equipped with a ${ }^{1} \mathrm{H}, \mathrm{BB}$ smartprobe. Referencing by residual solvents is relative to TMS. The actual concentration of the samples was estimated from integration relative to an external standard.

In situ reactions and NMR data. Dimethyl precursors/ER $\mathrm{R}_{\mathrm{n}}$ mixtures were generated within the glovebox, by dissolving the suitable amount of $\mathbf{1} \mathbf{M e}_{2}$ or $\mathbf{2} \mathbf{M e}_{2}$ in approximately $0.7 \mathrm{ml}$ of benzene$d_{6}$ or toluene- $d_{8}$ and by injecting the required volume of $\mathrm{ZnR}_{2}$ or $\mathrm{AlEt}_{3}$ with a micrometric syringe. Immediately after mixing, the tube was sealed, transferred out of the glovebox and inserted into a cold bath. $\mathbf{1}(\boldsymbol{\mu}-\mathbf{M e}) \mathbf{1}$ was synthesized in situ, by loading the suitable amount of $\mathbf{1} \mathbf{M e} \mathbf{e}_{2}$ and 0.5 equivalents of $\left[\mathrm{CPh}_{3}\right]\left[\mathrm{B}\left(\mathrm{C}_{6} \mathrm{~F}_{5}\right)_{4}\right]$ into a J Young NMR tube and adding approximately $0.7 \mathrm{ml}$ of toluene- $d_{8}$. Further reactions of $\mathbf{1}(\mu-\mathrm{Me}) \mathbf{1}$ with $\mathrm{ER}_{\mathrm{n}}$ were performed as described above. $\mathbf{2}\left(\mathbf{C}_{6} \mathbf{F}_{5}\right)_{2}$ was obtained by activating $2 \mathbf{M e}_{2}$ with 1.0 equivalents of $\left[\mathrm{CPh}_{3}\right]\left[\mathrm{B}\left(\mathrm{C}_{6} \mathrm{~F}_{5}\right)_{4}\right]$ in toluene- $d_{8}$ and by reacting the formed ion pair with 5 equivalents of $\mathrm{ZnMe}_{2}$ at room temperature.

$\mathrm{Cp}_{2} \mathrm{HfMe}_{2}\left(\mathbf{1 M e}_{2}\right) .{ }^{1} \mathrm{H}$ NMR (400 MHz, benzene- $\left.d_{6}, 298 \mathrm{~K}\right): \delta=5.65$ (s, Cp), $-0.33 \mathrm{ppm}(\mathrm{s}$, Me). ${ }^{13} \mathrm{C}\left\{{ }^{1} \mathrm{H}\right\}$ NMR (100.55 MHz, benzene- $\left.d_{6}, 298 \mathrm{~K}\right): \delta=110.0$ (s, Cp), $36.4 \mathrm{ppm}(\mathrm{s}, \mathrm{Me})$.

Cp ${ }_{2} \mathrm{HfMeEt}$ (1MeEt). ${ }^{1} \mathrm{H}$ NMR (400 MHz, benzene- $\left.d_{6}, 298 \mathrm{~K}\right): \delta=5.65$ (s, Cp), 1.41 (t, $\left.{ }^{3} \mathrm{~J}_{\mathrm{HH}}=7.7 \mathrm{~Hz}, \mathrm{CH}_{2} \mathrm{Me}\right), 0.89\left(\mathrm{q},{ }^{3} \mathrm{~J}_{\mathrm{HH}}=7.7 \mathrm{~Hz}, \mathrm{CH}_{2} \mathrm{Me}\right),-0.40 \mathrm{ppm}(\mathrm{s}, \mathrm{Me}) .{ }^{13} \mathrm{C}\left\{{ }^{1} \mathrm{H}\right\} \mathrm{NMR}(100.55$ MHz, benzene- $\left.d_{6}, 298 \mathrm{~K}\right): \delta=110.0(\mathrm{~s}, \mathrm{Cp}), 49.0\left(\mathrm{~s}, \mathrm{CH}_{2} \mathrm{Me}\right), 36.6(\mathrm{~s}, \mathrm{Me}), 16.0\left(\mathrm{~s}, \mathrm{CH}_{2} \mathrm{Me}\right)$.

$\mathrm{Cp}_{2} \mathrm{HfEt}_{2}\left(\mathbf{1 E t}_{2}\right) .{ }^{1} \mathrm{H}$ NMR $\left(400 \mathrm{MHz}\right.$, benzene- $\left.d_{6}, 298 \mathrm{~K}\right): \delta=5.66(\mathrm{~s}, \mathrm{Cp}), 1.43\left(\mathrm{t},{ }^{3} \mathrm{~J}_{\mathrm{HH}}=7.8 \mathrm{~Hz}\right.$, $\mathrm{CH}_{2} \mathrm{Me}$ ), $0.89 \mathrm{ppm}$ (q, $\left.{ }^{3} \mathrm{~J}_{\mathrm{HH}}=7.8 \mathrm{~Hz}, \mathrm{CH}_{2} \mathrm{Me}\right) .{ }^{13} \mathrm{C}\left\{{ }^{1} \mathrm{H}\right\} \quad \mathrm{NMR}\left(100.55 \mathrm{MHz}\right.$, benzene- $d_{6}$, 298K): $\delta=110.0$ (s, Cp), 49.1 (s, $\left.\mathrm{CH}_{2} \mathrm{Me}\right), 16.1\left(\mathrm{~s}, \mathrm{CH}_{2} \mathrm{Me}\right)$. 
$\left[\left(\mathrm{Cp}_{2} \mathrm{HfMe}\right)_{2}(\mu-\mathrm{Me})\right]\left[\mathrm{B}\left(\mathrm{C}_{6} \mathrm{~F}_{5}\right)_{4}\right](\mathbf{1}(\boldsymbol{\mu}-\mathrm{Me}) \mathbf{1}) .{ }^{1} \mathrm{H}$ NMR $\left(400 \mathrm{MHz}\right.$, toluene- $\left.d_{8}, 298 \mathrm{~K}\right): \delta=5.51$ (s, Cp), -0.32 (s, HfMe), $-1.21 \mathrm{ppm}(\mathrm{s}, \mathrm{Hf}(\mu-\mathrm{Me})) .{ }^{13} \mathrm{C}\left\{{ }^{1} \mathrm{H}\right\}$ NMR (400 MHz, toluene- $\left.d_{8}, 298 \mathrm{~K}\right)$ : $\delta=111.7$ (s, Cp), 40.0 (s, HfMe), 22.6 ppm (s, Hf( $\mu$-Me)). ${ }^{19} \mathrm{~F}$ NMR (376.65 MHz, toluene- $\left.d_{8}, 298 \mathrm{~K}\right)$ : $\delta=-131.8\left(\mathrm{brd}, o-\mathrm{F} \mathrm{B}\left(\mathrm{C}_{6} \mathrm{~F}_{5}\right)_{4}\right),-162.1\left(\mathrm{t},{ }^{3} \mathrm{~J}_{\mathrm{FF}}=20.8 \mathrm{~Hz}, p-\mathrm{F} \mathrm{B}\left(\mathrm{C}_{6} \mathrm{~F}_{5}\right)_{4}\right),-166.1 \mathrm{ppm}\left(\mathrm{m}, m-\mathrm{F} \mathrm{B}\left(\mathrm{C}_{6} \mathrm{~F}_{5}\right)_{4}\right)$.

$\left[\mathrm{Cp}_{2} \mathrm{Hf}(\mu-\mathrm{Me})_{2} \mathrm{AlMe}_{2}\right]\left[\mathrm{B}\left(\mathrm{C}_{6} \mathrm{~F}_{5}\right)_{4}\right](\mathbf{1}(\mu-\mathrm{Me}) \mathrm{Al}) .{ }^{1} \mathrm{H}$ NMR (400 MHz, toluene- $\left.d_{8}, 298 \mathrm{~K}\right)$ : $\delta=5.37$ (s, Cp), -0.07 (s, HfMe), $-0.75 \mathrm{ppm}(\mathrm{s}, \mathrm{AlMe}) .{ }^{13} \mathrm{C}\left\{{ }^{1} \mathrm{H}\right\}$ NMR (400 MHz, toluene- $\left.d_{8}, 298 \mathrm{~K}\right)$ : $\delta=113.4$ (s, Cp), 36.0 (s, HfMe), -7.05 ppm (s, AlMe). ${ }^{19} \mathrm{~F}$ NMR (376.65 MHz, toluene- $\left.d_{8}, 298 \mathrm{~K}\right): \delta=$ 131.8 (brd, $\left.o-\mathrm{F} \mathrm{B}\left(\mathrm{C}_{6} \mathrm{~F}_{5}\right)_{4}\right),-162.1\left(\mathrm{t},{ }^{3} \mathrm{~J}_{\mathrm{FF}}=20.8 \mathrm{~Hz}, p-\mathrm{F} \mathrm{B}\left(\mathrm{C}_{6} \mathrm{~F}_{5}\right)_{4}\right),-166.1 \mathrm{ppm}\left(\mathrm{m}, m-\mathrm{F} \mathrm{B}\left(\mathrm{C}_{6} \mathrm{~F}_{5}\right)_{4}\right)$.

$\mathbf{1}(\boldsymbol{\mu}-\mathrm{Me}) \mathbf{1}+\mathrm{ZnMe}_{2} .{ }^{1} \mathrm{H}$ NMR $\left(400 \mathrm{MHz}\right.$, toluene- $\left.d_{8}, 298 \mathrm{~K}\right): \delta=5.54(\mathrm{~s}, \mathrm{Cp}(\mathbf{a})), 5.21$ (s, Cp (b)), 1.85 (s, $\left.\mathrm{CH}_{2}(\mathbf{b})\right), 0.13$ (s, $\left.\mathrm{CH}_{2}(\mathbf{a})\right),-0.35$ (s, Me (a)), $-0.42 \mathrm{ppm}(\mathrm{s}, \mathrm{Me}(\mathbf{b})) .{ }^{13} \mathrm{C}\left\{{ }^{1} \mathrm{H}\right\} \mathrm{NMR}(400$ MHz, toluene- $\left.d_{8}, 298 \mathrm{~K}\right): \delta=111.1$ (s, Cp (a)), 109.9 (s, Cp (b)), 68.9 (s, $\left.\mathrm{CH}_{2}(\mathbf{a})\right), 65.3$ (s, $\mathrm{CH}_{2}(\mathbf{b})$ ), 36.1 (s, Me (a)), $25.8 \mathrm{ppm}$ (s, Me (b)). ${ }^{19} \mathrm{~F}$ NMR (376.65 MHz, toluene- $\left.d_{8}, 298 \mathrm{~K}\right): \delta=-131.5$ (brd, $o-\mathrm{F}$ $\left.\mathrm{B}\left(\mathrm{C}_{6} \mathrm{~F}_{5}\right)_{4}\right),-162.1\left(\mathrm{t},{ }^{3} \mathrm{~J}_{\mathrm{FF}}=20.8 \mathrm{~Hz}, p-\mathrm{F} \mathrm{B}\left(\mathrm{C}_{6} \mathrm{~F}_{5}\right)_{4}\right),-165.9 \mathrm{ppm}\left(\mathrm{m}, m-\mathrm{F} \mathrm{B}\left(\mathrm{C}_{6} \mathrm{~F}_{5}\right)_{4}\right)$.

$\mathbf{1}(\boldsymbol{\mu}-\mathbf{M e}) \mathbf{1}+\mathrm{ZnEt}_{2}$. Selected ${ }^{1} \mathrm{H}$ NMR resonances $\left(400 \mathrm{MHz}\right.$, toluene- $\left.d_{8}, 298 \mathrm{~K}\right): \delta=5.23(\mathrm{~s}$, H4), 5.02 (s, H2), 4.94 (s, H3), 4.79 (s, H1), 3.43 (dd, $\left.{ }^{3} \mathrm{~J}_{\mathrm{HH}}=16.4,12.0 \mathrm{~Hz}, \mathrm{H} 6\right), 3.03$ (dd, ${ }^{3} \mathrm{~J}_{\mathrm{HH}}=12.0$ ${ }^{2} \mathrm{~J}_{\mathrm{HH}}=3.3 \mathrm{~Hz}, \mathrm{H} 5 \mathrm{a}$ ), $1.40 \mathrm{ppm}$ (overlapped with $\mathbf{1 E t}_{2}, \mathrm{H} 5 \mathrm{~b}$ ). Selected ${ }^{13} \mathrm{C}\left\{{ }^{1} \mathrm{H}\right\}$ NMR resonances (100.55 MHz, toluene- $\left.d_{8}, 298 \mathrm{~K}\right): \delta=122.2$ (s, C6), 107.2 (s, C4), 105.9 (s, C2), 105.7 (s, C3), 105.1 (s, C1), $59.5 \mathrm{ppm}(\mathrm{s}, \mathrm{C} 5) .{ }^{19} \mathrm{~F}$ NMR $\left(376.65 \mathrm{MHz}\right.$, toluene- $\left.d_{8}, 298 \mathrm{~K}\right): \delta=-131.6\left(\mathrm{brd}, o-\mathrm{F} \mathrm{B}\left(\mathrm{C}_{6} \mathrm{~F}_{5}\right)_{4}\right),-$ $162.2\left(\mathrm{t},{ }^{3} \mathrm{~J}_{\mathrm{HH}}=20.8 \mathrm{~Hz}, p-\mathrm{F} \mathrm{B}\left(\mathrm{C}_{6} \mathrm{~F}_{5}\right)_{4}\right),-166.1 \mathrm{ppm}\left(\mathrm{m}, m-\mathrm{F} \mathrm{B}\left(\mathrm{C}_{6} \mathrm{~F}_{5}\right)_{4}\right)$.

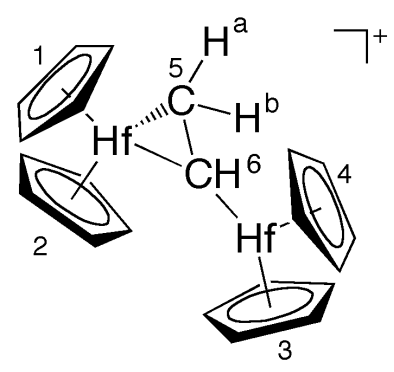

1( $\mu-$ Me) $1+$ AlEt $_{3}$. Selected ${ }^{1} \mathrm{H}$ NMR resonances $\left(400 \mathrm{MHz}\right.$, toluene- $\left.d_{8}, 298 \mathrm{~K}\right): \delta=5.87(\mathrm{~s}$, $\mathrm{Cp}), 5.36$ (s, Cp), 5.46 (s, Cp), $5.84(\mathrm{~s}, \mathrm{Cp}), 3.07$ (dd, $\left.{ }^{3} \mathrm{~J}_{\mathrm{HH}}=17.2,11.2 \mathrm{~Hz}, \mathrm{CH}\right), 0.89\left(\mathrm{~m}, \mathrm{CH}_{2}\right), 0.43$ $\operatorname{ppm}\left(\mathrm{m}, \mathrm{CH}_{2}\right)$. Selected ${ }^{13} \mathrm{C}\left\{{ }^{1} \mathrm{H}\right\}$ NMR resonances $\left(100.55 \mathrm{MHz}\right.$, toluene- $\left.d_{8}, 298 \mathrm{~K}\right): \delta=114.3(\mathrm{~s}, \mathrm{Cp})$, 113.5 (s, Cp), 105.1 (s, Cp), 104.6 (s, Cp), 69.8 (s, CH), 25.2 ppm (s, $\mathrm{CH}_{2}$ ).

[N-[2,6-Diisopropylphenyl]- $\alpha$-[2-isopropylphenyl]-6-(1-naphthalenyl)-2-pyridinemethanaminato]hafnium dimethyl (2Me $).{ }^{1} \mathrm{H}$ NMR (400 MHz, benzene- $\left.d_{6}, 298 \mathrm{~K}\right): \delta=8.58\left(\mathrm{~d},{ }^{3} \mathrm{~J}_{\mathrm{HH}}=7.7 \mathrm{~Hz}, \mathrm{H} 2\right)$, $8.25\left(\mathrm{~d},{ }^{3} \mathrm{~J}_{\mathrm{HH}}=8.6 \mathrm{~Hz}, \mathrm{H} 8\right), 7.82\left(\mathrm{~d},{ }^{3} \mathrm{~J}_{\mathrm{HH}}=7.7 \mathrm{~Hz}, \mathrm{H} 3\right), 7.72\left(\mathrm{dd},{ }^{3} \mathrm{~J}_{\mathrm{HH}}=7.6,{ }^{4} \mathrm{~J}_{\mathrm{HH}}=2.0 \mathrm{~Hz}, \mathrm{H} 5\right), 7.50(\mathrm{~d}$, $\left.{ }^{3} \mathrm{~J}_{\mathrm{HH}}=8.0 \mathrm{~Hz}, \mathrm{H} 12\right), 7.34$ (m, H24), 7.29 (m, H6+H7), 7.15 (m, H30+H31), 7.07 (m, H21+H29), 7.00 (m, H22+H23), 6.82 (t, $\left.{ }^{3} \mathrm{~J}_{\mathrm{HH}}=8.0 \mathrm{~Hz}, \mathrm{H} 13\right), 6.57$ (s, H16), 6.55 (d, $\left.{ }^{3} \mathrm{~J}_{\mathrm{HH}}=8.0 \mathrm{~Hz}, \mathrm{H} 14\right), 3.83$ (sept, $\left.{ }^{3} \mathrm{~J}_{\mathrm{HH}}=6.8 \mathrm{~Hz}, \mathrm{H} 27\right), 3.37$ (sept, $\left.{ }^{3} \mathrm{~J}_{\mathrm{HH}}=6.8 \mathrm{~Hz}, \mathrm{H} 33\right), 2.89$ (sept, $\left.{ }^{3} \mathrm{~J}_{\mathrm{HH}}=6.9 \mathrm{~Hz}, \mathrm{H} 19\right), 1.38\left(\mathrm{~d},{ }^{3} \mathrm{~J}_{\mathrm{HH}}=6.8 \mathrm{~Hz}\right.$, 
H34'), 1.37 (d, $\left.{ }^{3} \mathrm{~J}_{\mathrm{HH}}=6.8 \mathrm{~Hz}, \mathrm{H} 28\right), 1.18\left(\mathrm{~d},{ }^{3} \mathrm{~J}_{\mathrm{HH}}=6.8 \mathrm{~Hz}, \mathrm{H} 20\right), 1.14\left(\mathrm{~d},{ }^{3} \mathrm{~J}_{\mathrm{HH}}=6.8 \mathrm{~Hz}, \mathrm{H} 34\right), 0.96$ (s, $\mathrm{H} 35), 0.70$ (s, H36), 0.69 (d, ${ }^{3} \mathrm{~J}_{\mathrm{HH}}=6.8 \mathrm{~Hz}, \mathrm{H} 20$ '), $0.39 \mathrm{ppm}\left(\mathrm{d},{ }^{3} \mathrm{~J}_{\mathrm{HH}}=6.8 \mathrm{~Hz}, \mathrm{H} 28\right.$ '). ${ }^{13} \mathrm{C}\left\{{ }^{1} \mathrm{H}\right\} \mathrm{NMR}$ (100.55 MHz, benzene- $\left.d_{6}, 298 \mathrm{~K}\right): \delta=171.2$ (s, C15), 165.0 (s, C11), 148.0 (s, C26), 147.4 (s, C18), 147.0 (s, C32), 146.2 (s, C25), 144.7 (s, C10), 141.5 (s, C17), 141.4 (s, C13), 136.4 (s, C9), 134.8 (s, C2), 131.4 (s, C4), 130.8 (s, C24), 130.6 (s, C5), 130.5 (s, C3), 128.5 (s, overlapped with $\mathrm{C}_{6} \mathrm{D}_{6}, \mathrm{C} 22$ ), 127.6 (s, C6 or C7), 127.4 (s, C23), 126.7 (s, C30), 126.2 (s, C7 or C6), 126.1 (s, C21), 125.8 (s, C31), 125.2 (s, C29), 124.9 (s, C8), 121.1 (s, C12), 120.2 (s, C14), 77.4 (s, C16), 67.6 (s, C36), 63.5 (s, C35), 29.4 (s, C33), 29.3 (s, C19), 28.8 (s, C27), 28.1 (s, C28), 26.5 (s, C34'), 26.1 (s, C34), 25.8 (s, C20), 24.4 (s, C28'), 23.7 ppm (s, C20').

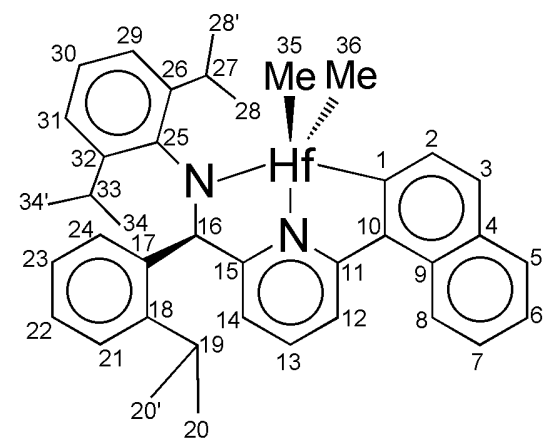

syn/anti [N-[2,6-Diisopropylphenyl]- $\alpha$-[2-isopropylphenyl]-6-(1-naphthalenyl)-2-pyridinemethanaminato]hafnium methyl-ethyl (2MeEt). Selected ${ }^{1} \mathrm{H}$ NMR resonances (400 MHz, benzene- $d_{6}$, $298 \mathrm{~K}): \delta=8.66\left(\mathrm{~d},{ }^{3} \mathrm{~J}_{\mathrm{HH}}=7.7 \mathrm{~Hz}, \mathrm{H} 2\right.$ syn or anti), 8.65 (d, ${ }^{3} \mathrm{~J}_{\mathrm{HH}}=7.7 \mathrm{~Hz}, \mathrm{H} 2$ syn or anti), 8.26 (d, overlapped with $\mathrm{HfEt}_{2}, \mathrm{H} 8$ syn+anti) 7.81 (d, ${ }^{3} \mathrm{~J}_{\mathrm{HH}}=7.7 \mathrm{~Hz}, \mathrm{H} 3 \mathrm{syn}+$ anti), 7.72 (d, overlapped with $\mathrm{HfEt}_{2}$, H5 syn+anti), 7.52 (d, overlapped with $\mathrm{HfEt}_{2}, \mathrm{H} 12$ syn+anti), 7.35 (m, overlapped with $\mathrm{HfEt}_{2}, \mathrm{H} 24$ syn+anti), 7.29 (m, overlapped with $\mathrm{HfEt}_{2}, \mathrm{H6}+\mathrm{H} 7$ syn+anti), 6.85 (t, overlapped with $\mathrm{HfEt}_{2}, \mathrm{H} 13$ syn+anti), 6.57 (s, overlapped with $\mathrm{HfEt}_{2}, \mathrm{H} 16$ syn+anti), 6.55 (d, overlapped with $\mathrm{HfEt}_{2}, \mathrm{H} 14$ syn+anti), 3.75 (sept, overlapped with $\mathrm{HfEt}_{2}$, H27 syn+anti), 3.37 (sept, overlapped with $\mathrm{HfEt}_{2}, \mathrm{H} 33$ syn+anti), 2.89 (sept, overlapped with $\mathrm{HfEt}_{2}, \mathrm{H} 19$ syn+anti), 1.75 (t, ${ }^{3} \mathrm{~J}_{\mathrm{HH}}=8.0 \mathrm{~Hz}, \mathrm{H} 36 \mathrm{syn}$ ), 1.53 (t, ${ }^{3} \mathrm{~J}_{\mathrm{HH}}=8.0 \mathrm{~Hz}, \mathrm{H} 37$ anti), 1.50 (m, H35 syn), 1.39 (overlapped with $\mathrm{HfEt}_{2}, \mathrm{H} 34^{\prime}+\mathrm{H} 28$ syn+anti), 1.28 (overlapped with $\mathrm{HfEt}_{2}, \mathrm{H} 36$ anti $+\mathrm{H} 20+\mathrm{H} 34$ syn+anti), 1.05 (m, overlapped with $\mathrm{HfEt}_{2}, \mathrm{H} 35$ syn), 1.04 (s, H35 anti), 0.84 (m, overlapped with $\mathrm{HfEt}_{2}, \mathrm{H} 36$ anti), 0.70 (m, overlapped with $\mathrm{HfEt}_{2}, \mathrm{H} 37$ syn+H20'syn+anti), 0.36 ppm (overlapped with $\mathrm{HfEt}_{2}, \mathrm{H} 28$ ' syn+anti). 


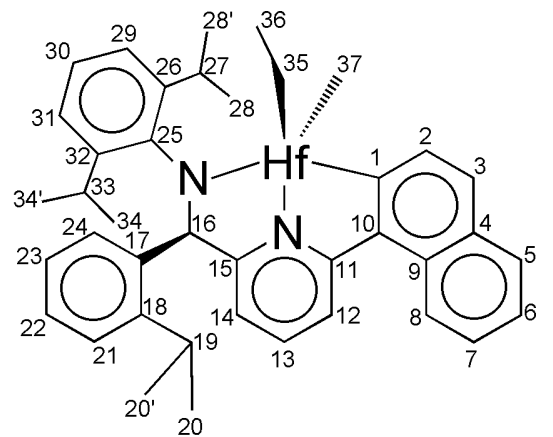

syn

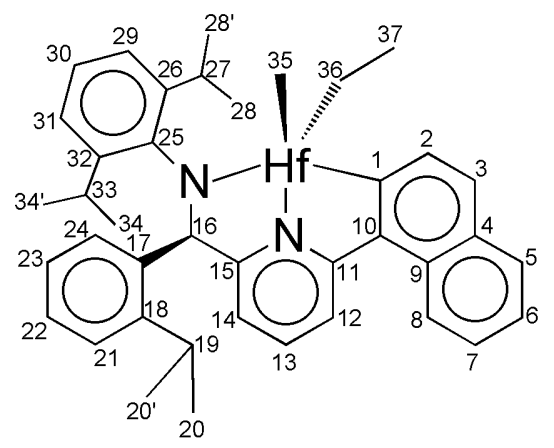

anti

[N-[2,6-Diisopropylphenyl]- $\alpha$-[2-isopropylphenyl]-6-(1-naphthalenyl)-2-pyridinemethanaminato]hafnium diethyl (2Et $\left.\mathbf{2}_{2}\right) .{ }^{1} \mathrm{H}$ NMR (400 MHz, toluene- $\left.d_{8}, 298 \mathrm{~K}\right): \delta=8.62\left(\mathrm{~d},{ }^{3} \mathrm{~J}_{\mathrm{HH}}=7.7 \mathrm{~Hz}, \mathrm{H} 2\right)$, $8.20\left(\mathrm{~d},{ }^{3} \mathrm{~J}_{\mathrm{HH}}=8.2 \mathrm{~Hz}, \mathrm{H} 8\right), 7.76\left(\mathrm{~d},{ }^{3} \mathrm{~J}_{\mathrm{HH}}=7.7 \mathrm{~Hz}, \mathrm{H} 3\right), 7.68\left(\mathrm{dd},{ }^{3} \mathrm{~J}_{\mathrm{HH}}=7.4,{ }^{4} \mathrm{~J}_{\mathrm{HH}}=2.0 \mathrm{~Hz}, \mathrm{H} 5\right), 7.50(\mathrm{~d}$, $\left.{ }^{3} \mathrm{~J}_{\mathrm{HH}}=8.0 \mathrm{~Hz}, \mathrm{H} 12\right), 7.30(\mathrm{~m}, \mathrm{H} 24), 7.26(\mathrm{~m}, \mathrm{H} 6+\mathrm{H} 7), 7.13\left(\mathrm{dd},{ }^{3} \mathrm{~J}_{\mathrm{HH}}=7.4\right.$ and $\left.1.9 \mathrm{~Hz}, \mathrm{H} 31\right), 7.07-7.00$ $(\mathrm{m}, \mathrm{H} 29+\mathrm{H} 30+\mathrm{H} 21+\mathrm{H} 22+\mathrm{H} 23), 6.91\left(\mathrm{t},{ }^{3} \mathrm{~J}_{\mathrm{HH}}=7.8 \mathrm{~Hz}, \mathrm{H} 13\right), 6.60\left(\mathrm{~d},{ }^{3} \mathrm{~J}_{\mathrm{HH}}=7.8 \mathrm{~Hz}, \mathrm{H} 14\right), 6.54(\mathrm{~s}, \mathrm{H} 16)$, 3.68 (sept, ${ }^{3} \mathrm{~J}_{\mathrm{HH}}=6.8 \mathrm{~Hz}, \mathrm{H} 27$ ), 3.68 (sept, ${ }^{3} \mathrm{~J}_{\mathrm{HH}}=6.8 \mathrm{~Hz}, \mathrm{H} 27$ ), 3.34 (sept, ${ }^{3} \mathrm{~J}_{\mathrm{HH}}=6.8 \mathrm{~Hz}, \mathrm{H} 33$ ), 2.87 (sept, $\left.{ }^{3} \mathrm{~J}_{\mathrm{HH}}=6.8 \mathrm{~Hz}, \mathrm{H} 19\right), 1.72\left(\mathrm{t},{ }^{3} \mathrm{~J}_{\mathrm{HH}}=8.0 \mathrm{~Hz}, \mathrm{H} 36\right), 1.44(\mathrm{~m}, \mathrm{H} 38+\mathrm{H} 35 \mathrm{~b}), 1.39\left(\mathrm{~d},{ }^{3} \mathrm{~J}_{\mathrm{HH}}=6.8 \mathrm{~Hz}\right.$, H34'), 1.34 (d, $\left.{ }^{3} \mathrm{~J}_{\mathrm{HH}}=6.8 \mathrm{~Hz}, \mathrm{H} 28\right), 1.18\left(\mathrm{~d},{ }^{3} \mathrm{~J}_{\mathrm{HH}}=6.8 \mathrm{~Hz}, \mathrm{H} 20\right), 1.15\left(\mathrm{~d},{ }^{3} \mathrm{~J}_{\mathrm{HH}}=6.8 \mathrm{~Hz}, \mathrm{H} 34\right), 1.08$ (m, H35a), 0.98 (m, H37b), 0.76 (m, H37a), 0.66 (d, ${ }^{3} \mathrm{~J}_{\mathrm{HH}}=6.8 \mathrm{~Hz}, \mathrm{H} 20$ '), $0.30 \mathrm{ppm}\left(\mathrm{d},{ }^{3} \mathrm{~J}_{\mathrm{HH}}=6.8 \mathrm{~Hz}\right.$, H28'). ${ }^{13} \mathrm{C}\left\{{ }^{1} \mathrm{H}\right\}$ NMR (100.55 MHz, toluene- $\left.d_{8}, 298 \mathrm{~K}\right): \delta=205.0$ (s, C1), 170.3 (s, C15), 164.1 (s, C11), 147.2 (s, C26), 146.5 (s, C18), 146.1 (s, C32), 145.9 (s, C25), 144.0 (s, C10), 141.1 (s, C17), 140.3 (s, C13), 135.4 (s, C9), 134.2 (s, C2), 130.5 (s, C4), 130.1 (s, C24), 129.6 (s, C5), 129.5 (s, C3), 127.5 (s, overlapped with $\mathrm{C}_{7} \mathrm{D}_{8}, \mathrm{C} 22$ ), 126.6 (s, C6 or C7), 126.5 (s, C23), 125.6 (s, C30), 125.2 (s, $\mathrm{C} 21$ or $\mathrm{C} 29$ ), 125.0 (s, overlapped with $\mathrm{C}_{7} \mathrm{D}_{8}, \mathrm{C} 7$ or C6), 124.8 (s, C31), 124.3 (s, C29 or C21), 123.9 (s, C8), 120.2 (s, C12), 119.1 (s, C14), 79.2 (s, C37), 76.6 (s, C16), 74.7 (s, C35), 28.5 (s, C19), 28.4 (s, C33), 28.0 (s, C27), 26.9 (s, C28), 25.9 (s, C34'), 25.2 (s, C34), 25.0 (s, C20), 23.7 (s, C28'), 22.8 (s, C20'), 11.7 (s, C38), 11.3 ppm (s, C36).

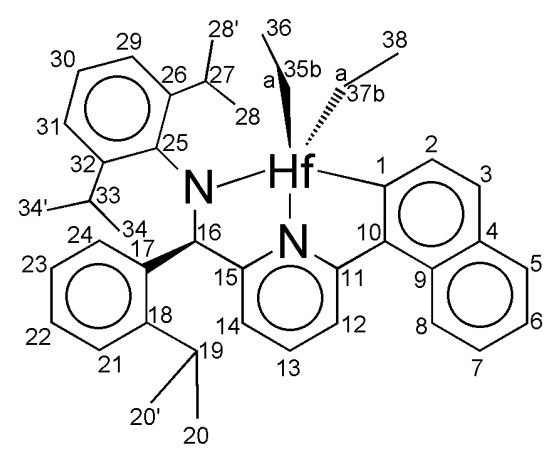

[N-[2,6-Diisopropylphenyl]- $\alpha$-[2-isopropylphenyl]-6-(1-naphthalenyl)-2-pyridinemethanaminato]hafnium bis-perfluorophenyl $\left(\mathbf{2}\left(\mathbf{C}_{6} \mathbf{F}_{5}\right)_{2}\right)$. Selected ${ }^{1} \mathrm{H}$ NMR resonances (400 MHz, toluene- $d_{8}$, 298K): $\delta=8.17\left(\mathrm{~d},{ }^{3} \mathrm{~J}_{\mathrm{HH}}=8.7 \mathrm{~Hz}, \mathrm{H} 8\right), 8.01\left(\mathrm{~d},{ }^{3} \mathrm{~J}_{\mathrm{HH}}=7.9 \mathrm{~Hz}, \mathrm{H} 2\right), 7.54(\mathrm{~d}, \mathrm{H} 3+\mathrm{H} 5+\mathrm{H} 24), 7.48(\mathrm{~m}$, 
H6+H12), 7.16 (m, H7), 6.87 (m, overlapped with other aromatic resonances, H13), 6.75 (s, H16), $6.53\left(\mathrm{~d},{ }^{3} \mathrm{~J}_{\mathrm{HH}}=7.8 \mathrm{~Hz}, \mathrm{H} 14\right), 3.25$ (sept, ${ }^{3} \mathrm{~J}_{\mathrm{HH}}=6.8 \mathrm{~Hz}, \mathrm{H} 27$ ), 3.03 (sept, ${ }^{3} \mathrm{~J}_{\mathrm{HH}}=6.8 \mathrm{~Hz}, \mathrm{H} 33$ ), 2.53 (sept, $\left.{ }^{3} \mathrm{~J}_{\mathrm{HH}}=6.8 \mathrm{~Hz}, \mathrm{H} 19\right), 1.26\left(\mathrm{~d},{ }^{3} \mathrm{~J}_{\mathrm{HH}}=6.8 \mathrm{~Hz}, \mathrm{H} 34\right), 1.07\left(\mathrm{~d},{ }^{3} \mathrm{~J}_{\mathrm{HH}}=6.8 \mathrm{~Hz}, \mathrm{H} 20\right), 0.61\left(\mathrm{~d},{ }^{3} \mathrm{~J}_{\mathrm{HH}}=6.8 \mathrm{~Hz}\right.$, H28), $0.56\left(\mathrm{~d},{ }^{3} \mathrm{~J}_{\mathrm{HH}}=6.8 \mathrm{~Hz}, \mathrm{H} 20^{\prime}\right), 0.24\left(\mathrm{~d},{ }^{3} \mathrm{~J}_{\mathrm{HH}}=6.8 \mathrm{~Hz}, \mathrm{H} 34\right),-0.03 \mathrm{ppm}\left(\mathrm{d},{ }^{3} \mathrm{~J}_{\mathrm{HH}}=6.8 \mathrm{~Hz}, \mathrm{H} 28^{\prime}\right)$. Selected ${ }^{13} \mathrm{C}\left\{{ }^{1} \mathrm{H}\right\}$ NMR resonances (100.55 MHz, toluene- $\left.d_{8}, 298 \mathrm{~K}\right): \delta=209.5$ (s, C1), 171.9 (s, C15), 165.4 (s, C11), 148.6 (s, C26), 147.8 (s, C18), 146.5 (s, C32), 143.0 (s, C10), 142.4 (s, C13), 130.7 (s, C3), 130.2 (s, C2), 124.1 (s, C8), 120.8 (s, C14), 120.4 (s, C12), 77.4 (s, C16), 29.0 (s, C33), 28.5 (s, C19), 28.3 (s, C27), 26.7 (s, C34'), 25.9 (s, C20), 25.0 (s, C28), 23.9 (s, C28'), 23.7 (s, C34), 22.0 ppm (s, C20'). ${ }^{19} \mathrm{~F}$ NMR (376.65 MHz, toluene- $\left.d_{8}, 298 \mathrm{~K}\right): \delta=-119.4$ (brd, $o-\mathrm{F}-\mathrm{C}_{6} \mathrm{~F}_{5}$ ), -121.4 (brd, $\left.o-\mathrm{F}-\mathrm{C}_{6} \mathrm{~F}_{5}\right),-125.5\left(\mathrm{brd}, o-\mathrm{F}-\mathrm{C}_{6} \mathrm{~F}_{5}\right),-151.3\left(\mathrm{t},{ }^{3} \mathrm{~J}_{\mathrm{FF}}=19.4 \mathrm{~Hz}, p-\mathrm{F}-\mathrm{C}_{6} \mathrm{~F}_{5}\right),-151.9\left(\mathrm{t},{ }^{3} \mathrm{~J}_{\mathrm{FF}}=19.4 \mathrm{~Hz}, p-\right.$ $\left.\mathrm{F}-\mathrm{C}_{6} \mathrm{~F}_{5}\right),-160.9\left(\mathrm{~m}, m-\mathrm{F}-\mathrm{C}_{6} \mathrm{~F}_{5}\right),-161.5 \mathrm{ppm}\left(\mathrm{m}, m-\mathrm{F}-\mathrm{C}_{6} \mathrm{~F}_{5}\right)$.

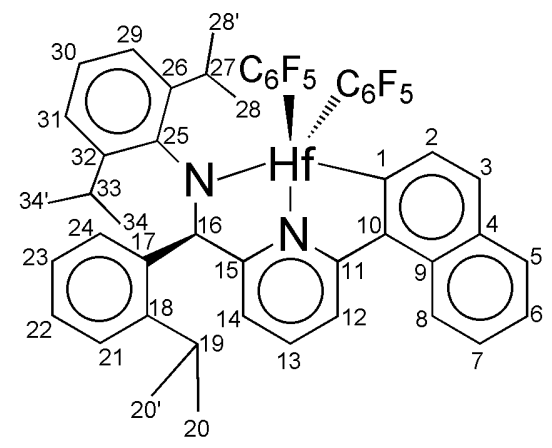

Kinetic measurements. Slow ethylation reactions were performed in J-Young tubes containing cold mixtures of $\mathbf{1} \mathbf{M e}_{2}$ and alkylating agent, which were inserted into the NMR probe and allowed to equilibrate at the desired instrumental temperature. The composition of the reaction mixture was monitored by means of ${ }^{1} \mathrm{H}$ NMR spectroscopy by acquiring a series of spectra as a function of time. Concentration versus time plots were obtained by referencing to an external standard and fitted by means of COPASI software package. ${ }^{32}$ The reaction plots were interpolated with a two-reactions kinetic model of the type:

$$
\begin{gathered}
\mathrm{Cp}_{2} \mathrm{HfMe}_{2}+\mathrm{E}(\mathrm{Et}) \stackrel{k_{1}}{\longrightarrow} \mathrm{Cp}_{2} \mathrm{HfMeEt}+\mathrm{E}(\mathrm{Me}) \\
\mathrm{Cp}_{2} \mathrm{HfMeEt}+\mathrm{E}(\mathrm{Et}) \stackrel{k_{2}}{\longrightarrow} \mathrm{Cp}_{2} \mathrm{HfEt}_{2}+\mathrm{E}(\mathrm{Me})
\end{gathered}
$$

where $\mathrm{E}(\mathrm{Et})$ and $\mathrm{E}(\mathrm{Me})$ are the total concentration of ethyl and methyl groups bound to $\mathrm{Al}$ or $\mathrm{Zn}$ atoms. Due to the presence of a large excess of alkylating agent, equilibrium effects were neglected. At higher temperatures, a decomposition reaction was added to the kinetic model to take into account the formation of ethane and improve the quality of the fitting.

Fast and reversible exchange rates between $\mathbf{2 E t _ { 2 }}$ and $\mathrm{E}(\mathrm{Et})_{\mathrm{n}}$ were quantified by means of twodimensional ${ }^{1} \mathrm{H}$ EXSY NMR spectroscopy, by using the $p f g$ version of the standard ${ }^{1} \mathrm{H}$ NOESY se- 
quence (noesygptp). Different values of spectral width, relaxation delay, mixing time $\left(\tau_{\mathrm{M}}\right)$ and number of transients were used according to the sample nature and concentration. Microscopic rate constants $\left(k^{\prime}, \mathrm{s}^{-1}\right)$ were calculated from the integration of the 2D spectra by using the software EXSYCALC ${ }^{33}$ and converted into second order rate constants $\left(k, \mathrm{M}^{-1} \mathrm{~s}^{-1}\right)$ correcting by the actual molar concentration of the exchanging sites. At least two experiments with different $\tau_{\mathrm{M}}$ values were acquired and the rate constant values (with relative standard deviations) were obtained from the average of all the values.

$\mathrm{T} 1$ values for the exchanging resonances were measured by means of ${ }^{1} \mathrm{H}$ inversion recovery experiments and, in all cases, no differences in $\mathrm{T} 1$ were observed.

Supporting Information. Additional kinetic experiments and NMR spectra.

Acknowledgements. This work is part of the Research Programme of the Dutch Polymer Institute, Eindhoven, The Netherlands (Project \#731). LR is thankful to Lucy Currie (University of East Anglia) for proofreading the manuscript.

The authors declare no competing financial interests.

\section{For the Table of Contents:}

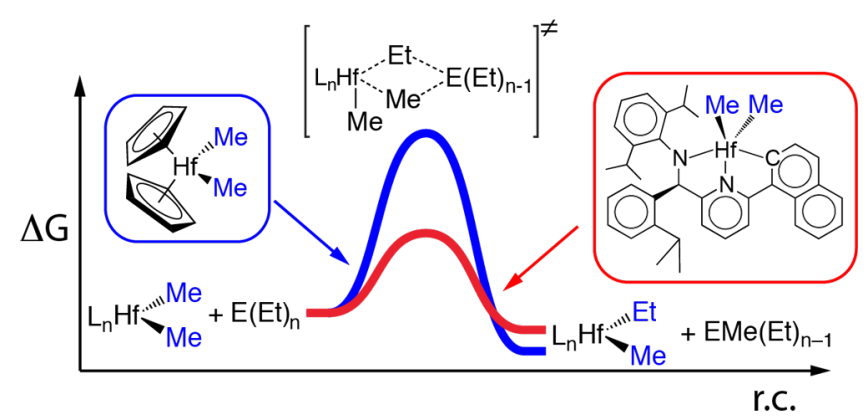

\section{References}

1) (a) Amin, S. B.; Marks, T. J. Angew. Chem. Int. Ed. 2008, 47, 2006-2025. (b) Makio, H.; Ochiai, T.; Mohri, J.; Takeda, K.; Shimazaki, T.; Usui, Y.; Matsuura, S.; Fujita, T. J. Am. Chem. Soc. 2013, 135, 8177-8180.

2) (a) Klimpel, M. G.; Eppinger, J.; Sirsch, P.; Scherer, W.; Anwander, R. Organometallics 2002, 21, 4021-4023. (b) Busico, V.; Cipullo, R.; Cutillo, F.; Friederichs, N.; Wang, B. J. Am. Chem. Soc. 2003, 125, 12402-12403. (c) Fan, G.; Dong, J. Y. J. Mol. Catal. A: Chem. 2005, 236, 246-252. (d) Bhriain, N. N.; Brintzinger, H. H.; Ruchatz, D.; Fink, G. Macromolecules 2005, 38, 2056-2063. (e) Quintanilla, E.; di Lena, F.; Chen, P. Chem. Commun. 2006, 4309-4311.

3) Zijlstra, H. S.; Harder, S. Eur. J. Inorg. Chem. 2015, 19-43.

4) (a) Lieber, S.; Brintzinger, H. H. Macromolecules 2000, 33, 9192-9199. (b) Bogaert, S.; Chenal, T.; Mortreux, A.; Carpentier, J. F J. Mol. Catal. A: Chem. 2002, 190, 207-214. (c) Tynys, A.; Saarinen, T.; Hakala, K.; Helaja, T.; Vanne, T.; Lehmus, P.; Löfgren, B. Macromol. Chem. Phys. 2005, 206, 1043-1056. (d) Busico, V.; Cipullo, R.; Pellecchia, R.; Talarico, G.; Razavi, A. Macromolecules 2009, 42, 1789-1791. (e) Rouholahnejad, F.; Mathis, D.; Chen. P. Organometallics 2010, 29, 294-302. (f) Camara, J. M.; Petros, R. A.; Norton, J. R. J. Am. Chem. Soc. 2011, 133, 5263-5273. 
5) (a) Coates, G. W.; Hustad, P. D.; Reinartz, S. Angew. Chem. Int. Ed 2002, 41, 2236-2257. (b) Domski, G. J.; Rose, J. M.; Coates, G. W.; Bolig, A. D.; Brookhart, M. Prog. Polym. Sci. 2007, 32, 30-92.

6) Sita, L. Angew. Chem. Int. Ed. 2009, 48, 2464-2472.

7) General references on CCTP: (a) Van Meurs, M.; Britovsek, G. J. P.; Gibson, V. C.; Cohen, S. A. J. Am. Chem. Soc. 2005, 127, 9913-9923. (b) Kempe, R. Chem. Eur. J. 2007, 13, 2764-2773. (c) Valente, A.; Mortreux, A.; Visseaux, M.; Zinck, P. Chem. Rev. 2013, 113, 3836-3857. (d) Ribeiro, R.; Ruivo, R.; Nsiri, H.; Norsic, S.; D’Agosto, F.; Perrin, L.; Boisson, C. ACS Catal. 2016, 6, 851-860.

8) (a) Hustad, P. D.; Kuhlman, R. L.; Arriola, D. J.; Carnahan, E. M.; Wenzel, T. T. Macromolecules 2007, 40, 7061-7064. (b) Zhang, W.; Sita, L. R. J. Am. Chem. Soc. 2008, 130, 442-443.

9) (a) Bochmann, M.; Lancaster, S. J. Angew. Chem. Int. Ed. 1994, 33, 1634-1637. (b) Bochmann, M.; Lancaster, S. J. J. Organomet. Chem. 1995, 497, 55-59. (c) Götz, C.; Rau, A.; Luft, G. J. Mol. Catal. A: Chem. 2002, 184, 95-110. (d) Bryliakov, K. P.; Semikolenova, N. V.; Yudaev, D. V.; Zakharov, V. A.; Brintzinger, H. H., Ystenes, M.; Rytter, E.; Talsi, E. P.; J. Organomet. Chem. 2003, 683, 92-102. (e) Bryliakov, K. P.; Talsi, E. P.; Voskoboynikov, A. Z.; Lancaster, S. J.; Bochmann, M. Organometallics 2008, 27, 6333-6342. (f) Mathis, D.; Couzijn, E. P. A.; Chen, P. Organometallics 2011, 30, 3834-3843. (g) Rocchigiani, L.; Busico, V.; Pastore A.; Macchioni, A. Dalton Trans. 2013, $42,9104-9111$.

10) Dettenrieder, N.; Hollfelder, C. O.; Jende, L. N.; Maichle-Mössmer, C.; Anwander, R. Organometallics 2014, 33, 1528-1531.

11) Soshnikov, I. E.; Semikolenova, N. V.; Antonov, A. A.; Bryliakov, K. P.; Zakharov, V. A.; Talsi, E. P. Organometallics 2014, 33, 2583-2587.

12) Bryliakov, K. P.; Semikolenova, N. V.; Zakharov, V. A.; Talsi, E. P. Organometallics 2004, 23, 5375-5378.

13) Soshnikov, I. E.; Semikolenova, N. V.; Bushmelev, A. N.; Bryliakov, K. P.; Lyakin, O. Y.; Redshaw, C.; Zakharov, V. A.; Talsi, E. P. Organometallics 2009, 28, 6003-6013.

14) (a) Boussie, T. R.; Diamond, G. M.; Goh, C.; Hall, K. A.; LaPointe, A. M.; Leclerc, M. K.; Lund, C.; Murphy, V.; Shoemaker, J. A. W.; Turner, H.; Rosen, R. K.; Stevens, J. C.; Alfano, F.; Busico, V.; Cipullo, R.; Talarico, G. Angew. Chem. Int. Ed. 2006, 45, 3278-3283. (b) Zuccaccia, C.; Macchioni, A.; Busico, V.; Cipullo, R.; Talarico, G.; Alfano, F.; Boone, H. W.; Frazier, K. A.; Hustad, P. D.; Stevens, J. C.; Vosejpka, P. C.; Abboud, K. A. J. Am. Chem. Soc. 2008, 130, 10354-10368. (c) Zuccaccia, C.; Busico, V.; Cipullo, R.; Talarico, G.; Froese, R. D. J.; Vosejpka, P. C.; Hustad, P. D.; Macchioni, A. Organometallics 2009, 28, 5445-5458. (d) Li, G.; Zuccaccia, C.; Tedesco, C.; D'Auria, I.; Macchioni, A.; Pellecchia, C. Chem. Eur. J. 2014, 20, 232-244.

15) (a) Arriola, D. J.; Carnahan, E. M.; Hustad, P. D.; Kuhlman, R. L.; Wenzel, T. T. Science 2006, 312, 714-719. (b) Hustad, P. D.; Kuhlman, R. L.; Carnahan, E. M.; Wenzel, T. T.; Arriola, D. J. Macromolecules 2008, 41, 4081-4089.

16) Rocchigiani, L.; Busico, V.; Pastore, A.; Talarico, G.; Macchioni, A. Angew. Chem. Int. Ed. 2014, 53, 2157-2161.

17 ) (a) Liu, Z; Somsook, E.; White, C.B.; Rosaaen, K. A.; Landis, C. R. J. Am. Chem. Soc. 2001, 123, 11193-11207. (b) Christianson, M. D.; E. H. P. Tan, Landis, C. R. J. Am. Chem. Soc. 2010, 132, 11461-11463. (c) Rocchigiani, L.; Ciancaleoni, G.; Zuccaccia, C.; Macchioni, A. Angew. Chem. Int. Ed. 2011, 50, 11752-11755. (d) Rocchigiani, L.; Macchioni, A. Dalton Trans. 2016, 45, 27852790.

18) (a) Brown, T. L.; Murrell, L. L. J. Am. Chem. Soc. 1972, 94, 378-384. (b) Jeffery, E. A.; Mole, T. Aust. J. Chem. 1973, 26, 739-748.

19) Williams, K. C.; Brown, T. L. J. Am. Chem. Soc. 1966, 88, 5460-5465.

20) At the coalescence temperature, $k=\frac{\pi \Delta v_{0}}{\sqrt{2}}\left(\Delta v_{0}\right.$ is the distance in Hz between the signals in the completely resolved spectrum).

21) Siedle, A. R.; Newmark, R. A.; Schroepfer, J. N.; Lyon. P A. Organometallics 1991, 10, 400-404. 

301-308.

22) Siedle, A. R.; Newmark, R. A.; Lamanna, W. M.; Schroepfer, J. N. Polyhedron 1990, 9 ,

23) It is known that the average E-Me bond energy is larger for Al compared with that of $\mathrm{Zn}$ (65.5 vs. $42.3 \mathrm{kcal} / \mathrm{mol}$ ): O'Neill, M. E.; Wade, K. in Comprehensive organometallic chemistry; Wilkinson, G., Stone, F. G. A., Abel, E.W. eds; Pergamon Press, Oxford (1982).

24) Perrin, C. L.; Dwyer, T. J. Chem. Rev. 1990, 90, 935-967.

25) Petros, R. A.; Norton, J. R. Organometallics 2004, 23, 5105-5107.

26) Neuhaus, D.; Williamson, M. P. The Nuclear Overhauser Effect in Structural and Conformational Analysis, 2nd ed., Wiley-VCH, Weinheim, 2000.

26) Ivanov, S. V.; Peryshkov, D. W.; Miller, S. M.; Anderson, O. P.; Rappé, A. K.; Strauss, S. H. J. Fluor. Chem. 2012, 143, 99-102.

28) Bochmann, M.; Sarsfield, M. J. Organometallics 1998, 17, 5908-5912.

29) (a) Sadow, A.D.; Tilley, T. D. J. Am. Chem. Soc. 2002, 124, 6814-6815. (b) Sadow, A.D.; Tilley, T. D. J. Am. Chem. Soc. 2003, 125, 9462-9475. (c) Sadow, A.D.; Tilley, T. D. Organometallics 2003, 22, 3577-3585.

30) (a) Walker, D. A.; Woodman, T. J.; Hughes, D. L.; Bochmann, M. Organometallics 2001, 20, 3772-3776.

31) Tonzetich, Z. J.; Schrock, R. R. Polyhedron 2006, 25, 469-476.

32) http://copasi.org/

33) http://mestrelab.com/software/ 